\title{
The Use of World Water Resources in the Irrigation of Field Cultivations
}

\author{
Amadeusz Walczak ${ }^{1}$ \\ 1 Wroclaw University of Environmental and Life Sciences, Institute of Environmental Protection and \\ Development, pl. Grunwaldzki 24, 50-363 Wrocław, Poland \\ e-mail: amadeusz.walczak@upwr.edu.pl
}

\begin{abstract}
The paper concerns evaluation of the exploitation of the world's water resources for irrigating field crops. It was determined that the volume of water used in 2020 in all sectors of the economy in relation to the world's freshwater resources will amount to 31 to $38 \%$ of the available resources. It has been found that globally, in the period 1900-2100, the agricultural sector has the highest consumption of fresh water. Therefore, there is a need for rational use of water, especially when irrigating field crops. Hence, the paper describes the methods of evaluating the effectiveness of irrigation. The indicators from the Water use efficiency group, which consider the yield obtained from a given area and the sum of irrigation doses, were considered the most reliable form of evaluation. Determining the indicator should also be accompanied by a presentation of the scope of work related to irrigation, water quality, cultivation techniques, fertilization and environmental conditions of the growing season. The work characterizes the selected pressure irrigation systems, considering their advantages and disadvantages. On this basis, the paper presents the adaptation of the SWOT analysis for two irrigation systems: a reel sprinkler with a water cannon and a drip tape.
\end{abstract}

Keywords: SWOT analysis; drip lines; sprinkler irrigation; prediction; irrigation systems; world water resources; water use efficiency (WUE)

\section{INTRODUTION}

One of the priorities of the current generation is the constant economic growth. Social and economic objectives should be realized in conformance with the principles of sustainable development. This pertains e.g. to the rational use of natural resources of the Earth - including water (Alyami \& Rezgui, 2012). Water is the main component of the hydrosphere and atmosphere, and its presence and availability is the condition for the existence of the biosphere (Kucharik et al. 2000; Jackson et al. 2001). The fundamental classification that can be applied in relation to water resources is the division into fresh and salt water. It is estimated that the total resources of salt water amount to 1.386 million $\mathrm{km}^{3}$, and those of fresh water are in the range of 34.7-42.6 thousand $\mathrm{km}^{3}$ (Shiklomanov 2000; Cassardo \& Jones 2011). These are values whose variation results from the continual and volatile water cycle in nature.(Jackson et al. 2001; Oki \& Kanae 2006). In the economic development, the primary role is that of fresh water which is only a small fraction in relation to the total water resources of the Earth, at approximately 2.5-3.0\% (Courtland 2008; Unies 2009). In the context of water use, the economic system can be divided into three main sectors: agriculture, industry, and domestic use. Worldwide, the shares of water use in the individual sectors are hard to determine. The determining factor is the anthropogenic activity - social and economic development, and numerous changes related to the natural environment (Foley et al. 2005; Cassardo \& Jones 2011). The attempts at the estimation of the scale of water use, undertaken so far with division for the sectors, come from e.g. the statistical analyses produced by research centres (The United Nations World Water Development, Food 
and Agriculture Organization of the United Nations - FAO, International Commission on Irrigation and Drainage, Eurostat, Statistics Poland (GUS)). In their analyses, those organisations refer to regional institutions. Unfortunately, the data are often incomplete, as they are sourced from the documentation that is often not quite up-to-date. This is the case, in particular, on the world scale. As an example, Aquastat, which is a global information system working for the FAO, manages the data relating to annual water use in the sectors of agriculture, industry and domestic use; for Poland, the most recent information comes from 2017 (Eliasson et al. 2005; United 2020). In the case of Eurostat, the corresponding data for Poland are from the same year (Eurostat Statistics Explained 2020), but Statistics Poland (GUS) data currently under analysis relate to the year 2020 (Production of agricultural and horticultural crops in 2018 2019). It should be emphasized that Poland is an example of a country for which the data is updated. In the Aquastat website, the latest data for some countries come from 2012 (Switzerland, Turkey, Libya), from 2007 (Thailand, Norway) and even from earlier years. Moreover, it should be mentioned that the data can be incomplete (Eliasson et al. 2005; United 2020). In the era of such dynamic climate changes, when we deal with extreme phenomena of drought or rain, in order to make the most accurate conclusions, these data must be complete and the latest. There are gaps in the timelines amounting to several years, which make it impossible to capture the trends in water use. Another source of information includes independent publications prepared by research entities or by organisations such as the International Water Management Institute. For example, Wada and Bierkens developed a model with the name BIWSI (The blue water sustainability index). It is a tool which allows determining the intensity of water use in a given area. The basic data used by the algorithm are the location and volume of resources of surface waters or non-renewable resources of underground waters. The model estimates the degree of degradation of a given resource, and the prospects of its renewal (Wada $\&$ Bierkens 2014). Members of the Organisation for Economic Co-operation and Development developed the so-called ENV-Linkages model. It is constructed on the basis of the data from 25 largest national economies. The data used in the model are sourced from national statistical agencies and relate to purely economic aspects, such as commerce or transport (Chateau et al. 2014). The strength of those solutions is the possibility of presenting scenarios of use of fresh water resources. The common information resulting from the analysed models is an increase of water use in all the sectors of the economy. This is illustrated in Figure 1, which presents arithmetic means of the values of annual use of water resources from 1900 till the present, and a forecast until the year 2100 .

At present, the use of the world water resources amounts to nearly 4 thousand $\mathrm{km}^{3}$ a year. This value, however, should not be compared with the world resources of fresh water (34.7 42.6 thousand $\mathrm{km}^{3}$ ). Scientists classify the total fresh water resources in three categories of blue, green and grey water. This classification originates from the concept of the water footprint, i.e. the analysis of the direct and indirect use of water in the production of goods. The term blue water relates to the surface and underground waters (lakes, rivers, glaciers, snow, ground water), green water relates to the water cycle in the soil-plant-atmosphere continuum, and grey water relates to polluted water (Hoekstra \& Mekonnen 2012; Vanham \& Bidoglio 2013). The values analysed in Figure 1 relate only to the blue water resources, excluding glaciers, but including fresh ground waters. This accounts for as little as approx. $30 \%$ of fresh water resources (AQUASTAT - FAO's global water information system 2014). In this case, the volume of water that will be used for economic purposes in 2020 will be from 31 to $38 \%$ of the available water resources. This might not seem much, but the significant spatial and temporal variation of water availability in the world causes the occurrence of the water stress phenomenon in certain parts of the globe, such as north Africa, south Europe, the Middle East, the western parts of both Americas (Pimentel et al. 2007; GRID-Arendal 2009; Cassardo \& Jones 2011). Already now, local and temporary limitations are noted in the availability of water for food production, and in the future - with progressing climate change - water shortage can become the cause of increasingly frequent migrations of populations (Vörösmarty et al. 2000; Rockström et al. 2009; Gerten et al. 2011).

On the basis of the information presented in Figure 1, one can note an increase in water use. The tendency is the least pronounced in the 


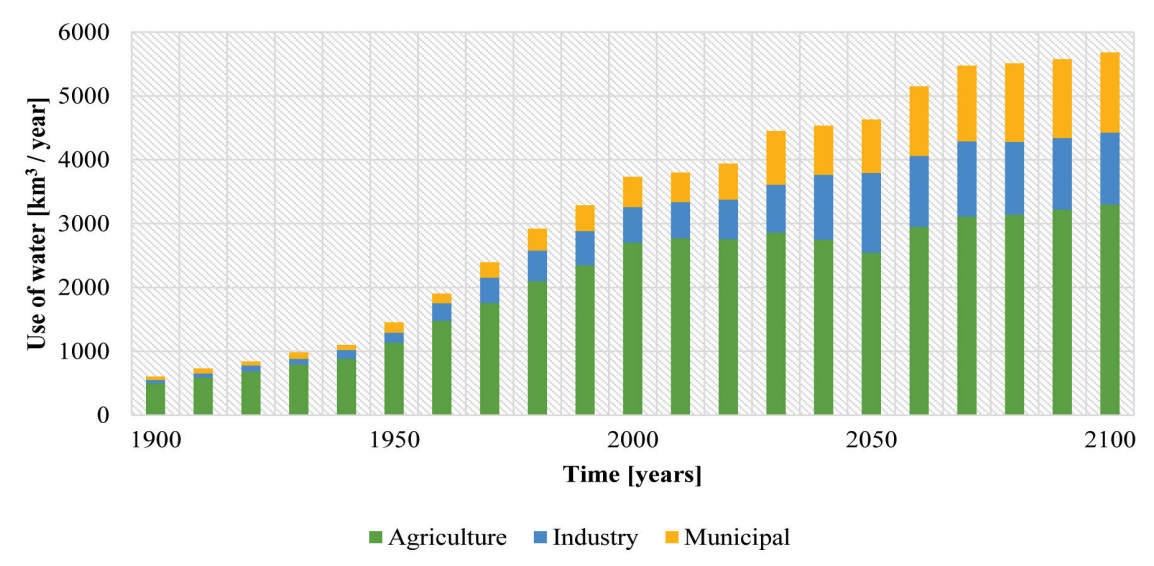

Figure 1. World use of water in selected sectors of the economy in the years 1900-2020 and forecast till 2100 (Gleick 2003; OECD 2012; Eales \& Clifford 2013; Wada \& Bierkens 2014; Shirazi \& Kargari 2015; The

Source - International Water Association 2015; Food Agric Organ United Nations 2020; PURE-H2O 2021).

agricultural sector. It is estimated that in 2020, the use of water in that branch of the economy will amount to about $2800 \mathrm{~km}^{3} /$ year, and in 2100 - to $3300 \mathrm{~km}^{3} /$ year. This shows that the increase in water requirements is small $(\sim 20 \%)$. In turn, the increments in the same years in the sectors of industry and domestic needs to amount to as much as $\sim 80 \%$ and $\sim 120 \%$. However, due to the ratio of water use in agriculture to the total value, it is this sector of the economy that draws special attention (Rosegrant et al.2002). It is estimated that in 2020 it will be $\sim 70 \%$, but in 2100 - as much as $\sim 60 \%$. Water use in the sector of agriculture is related primarily to irrigation (OECD 2012; Wada \& Bierkens 2014). This results from the significant demand for food, in turn resulting from the continuous growth of the population (Arnell 1999; Vörösmarty et al. 2000; Jackson et al. 2001; Witze 2018). An additional factor which causes a high index of water use in the agricultural sector is the climate change, the effect of which is the increasingly frequent occurrence of agricultural drought, determining the use of irrigation systems for cultivations (Arnell 1999; Gleick 2003; Huntington 2006). In order to improve the status of the world water management, one of the key activities is the intensification of irrigation efficiency through the application of enhanced water application techniques. Taking the above under consideration, it is advisable to undertake the efforts aimed at an improvement of water management, in line with the principles of sustainable development. For this reason, the present study undertakes an attempt at an analysis of the effectiveness of selected irrigation techniques and their evaluation in the aspects of water efficiency and operation.

\section{SELECTED IRRIGATION EFFICIENCY INDICATORS}

Two approaches in terms of the possibility of using irrigation systems in agriculture can be distinguished. One of them is rainfeed agriculture. It is a form of agriculture in which the water for irrigation purposes comes exclusively from precipitation. Such water resources can be managed by capturing excess water during rainy seasons and using it during dry periods (Rockström et al. 2010). The second approach is irrigated agriculture, in which the primary task is to ensure an optimal air-water regime of the soil by using water from various subsurface and surface resources (Kuśnierz et al. 2018). Both approaches should be increasingly used on a global scale. This is evidenced by the fact that in 2018 only $20 \%$ of the areas intended for agriculture were irrigated (275 million hectares), but these areas generate as much as $40 \%$ of global food production (Chateau et al. 2014, Dudu \& Chumi 2008). Moreover, given the constantly growing increase in the world population, one should expect production intensification in the agricultural sector. At the same time, taking into account the changing climatic conditions, more and more attention should be paid to the precision in regulating the operation of irrigation systems (Elgaali et al. 2007; Wu et al. 2010; Woznicki et al. 2015), which is assessed broadly as irrigation efficiency.

The efficiency of irrigation can be assessed based on several indicators, they are determined by the greenhouse (pot) experiments or the experiments under open field conditions (Figure 2). As part of the first approach, it is possible to precisely 


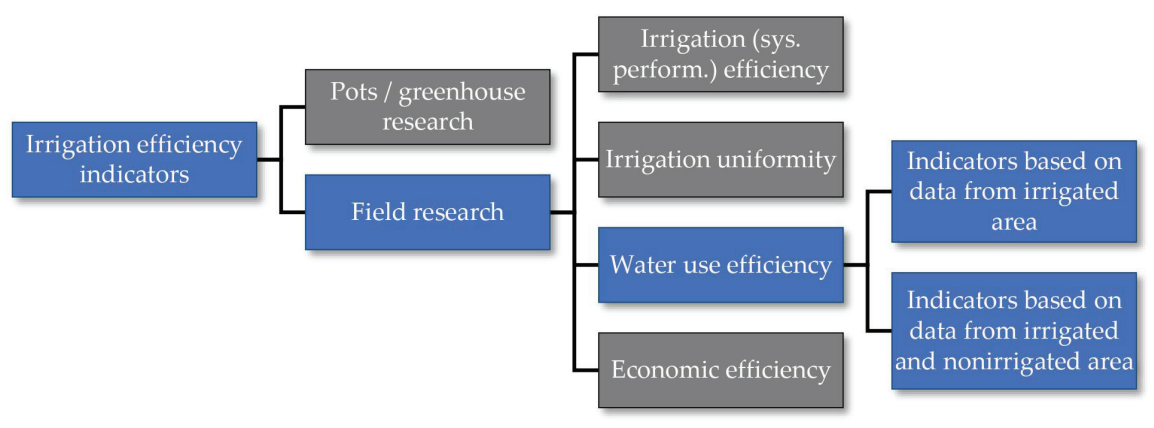

Figure 2. Division of irrigation price indices. Direction of analyses.

regulate the air-water relations of the rhizosphere. Thus, the purpose of such experiments may also be to check the differentiating factors, e.g., the regime of maintained humidity for yielding (Kim et al. 2016; Sarkar et al. 2018; Jama-Rodzeńska et al. 2020). The second group of studies, due to the diverse atmospheric, hydrological and soil conditions in independent growing seasons, requires a wider scope of work. Extending the scale involves conducting experiments in several independent fields (Kaya et al. 2015) or in a longer period: usually 2-3 years (Żarski et al. 2020), but data can be collected for as long as 8-10 years (De Pascale et al. 2003). Field trials are closer to reality than pot trials, so they should be used when identifying the methods to increase yield. Accordingly, the irrigation efficiency of open field crops is the subject of the following considerations.

The scope of the proposed description of irrigation efficiency indicators on the field scale can be divided into four basic groups (Figure 2). The first is Irrigation (system performance) efficiency - IE [\%]. This is the coefficient which concerns the possibility of storing water by the rhizosphere and its use by crops in its most common version (Burt 1997; Hamdy et al. 2007; Nair et al. 2013). In other words, the coefficient from this group determines the proportion of water consumed by plants in relation to the total dose applied by the irrigation system. This proportion depends on the type of irrigation system used. For example, for hand move sprinkler irrigation system, the IE coefficient is only $>65 \%$, for the surface drip line $>$ $85 \%$, and for the subsurface drip line it is even> 95\% (Howell 2006; Irmak et al. 2011). The IE value also depends on the climatic zone in which the irrigation system is used. The same sprinkler irrigation system has an irrigation efficiency of $85 \%$ in central Europe and only $60 \%$ in the Middle East (Sauer et al. 2010). Another group concerns
Irrigation uniformity. These are indicators that assess the homogeneity of water application to soil. This is an important type of assessment, as uneven water application can result in under-irrigation or over-irrigation. In the case of sprinkler irrigation, the causes of this unevenness may be different topographic or soil conditions, as well as incorrect selection of pipeline diameters, nozzles, overlap of the sprinkler field of action or wind (Denisov et al. 2002; Dechmi et al. 2003; Irmak et al. 2011; Nair et al. 2013; Zhang et al. 2013; Salvatierra-Bellido et al. 2018). The consideration of the efficiency of irrigation in economic aspects is a separate issue. Such analyses include not only the factors of water consumption and the size of the obtained crops, but also, inter alia, unit cost for water and system operation and sales profit, the result of which should be the profitability of the project (Ali et al. 2007; Dudu \& Chumi 2008; Dunage et al. 2009; Sauer et al. 2010).

On the other hand, the Water use efficiency indicators are the most frequently used assessment methods. They indicate the relationship between the obtained yield and water consumption for irrigation purposes. This is important from the agricultural perspective, as yielding is a direct response to the irrigation treatments carried out. Among them, two groups of indicators can be distinguished. The first one relates only to the number of crops and water consumption within irrigated areas:

- WUE (Water Use Efficiency) is an indicator related to productivity, therefore WP (Water Production) and IWUE - Irrigation Water Use Efficiency are alternative names. In the literature, the WUE indicator (WP, IWUE) is expressed in several forms (Howell 2006; Boutraa 2010; Irmak et al. 2011; Singh et al. 2012; Nair et al. 2013; Chai et al. 2014; Jägermeyr et al. 2015; Chai et al. 2016; Zhuo \& Hoekstra 2017; De Pascale et al. 2018): 


$$
\begin{aligned}
& \text { WUE }=\frac{\text { Crop yield }}{I} \\
& \text { WUE }=\frac{\text { Crop yield }}{\text { ET }} \\
& \text { WUE }=\frac{\text { Crop yield }}{P_{e}+I+\text { SW }}
\end{aligned}
$$

where: WUE(WP, IWUE) - Water use efficiency (Water production, Irrigation Water Use Efficiency) $\left[\mathrm{kg} \cdot \mathrm{ha}^{-1} \cdot \mathrm{mm}^{-1}\right]$, Crop yeld - as grain, seed or total dry matter $\left[\mathrm{kg} \mathrm{ha}^{-1}\right]$,

$I$ - water used for irrigation purposes (using irrigation systems) [mm],

ET - water used by plants. ET measurement is performed using a lysimeter (Liu et al. 2002; Kang \& Wan 2005),

$P e+I+S W-$ effective rainfall $(P e)$, water used for the irrigation purposes $(I)$, the difference between the water content at the beginning and at the end of the growing season (storage water) $(S W)[\mathrm{mm}]$.

The second group of indicators are assessment methods that include the analysis of crops from the irrigated and non-irrigated areas. Among them we can distinguish:
- $\mathrm{I}_{\mathrm{WUE}}$ (Irrigation Water Use Efficiency) - (or WUE $_{\mathrm{I}}$ ) is an extension of the WUE indicator and is also denoted as such. It is defined by (Howell 2006; Irmak et al. 2011; Singh et al. 2012; Chai et al. 2014; Chai et al. 2016; Ullah et al. 2019):

$$
I_{W U E}=\frac{Y_{i}-Y_{r}}{I}
$$

where: $I_{W U E}$ - water use efficiency factor from irrigation $\left[\mathrm{kg} \cdot \mathrm{ha}^{-1} \cdot \mathrm{mm}^{-1}\right]$,

$Y_{i}$ - yield from the irrigated field $\left[\mathrm{kg} \mathrm{ha}^{-1}\right]$, $Y_{r}$-yield from non-irrigated field $\left[\mathrm{kg} \mathrm{ha}^{-1}\right]$, I - amount of water used for irrigation [mm].

- $E T_{\text {WUE }}$ (Evapotranspiration Water Use Efficiency) -also referred to as WUE, $\mathrm{C}_{\text {wUE }}$ or ET is a development of the WUE indicator. It is defined by (Howell 2006; Irmak et al. 2011; Singh et al. 2012; Nair et al. 2013; Ullah et al. 2019):

$$
\mathrm{ET}_{\mathrm{WUE}}=\frac{\mathrm{Y}_{\mathrm{i}}-\mathrm{Y}_{\mathrm{r}}}{\mathrm{ET}_{\mathrm{i}}-\mathrm{ET}_{\mathrm{r}}}
$$

where: $E T_{W U E}-$ water use efficiency factor from irrigation $\left[\mathrm{kg} \cdot \mathrm{ha}^{-1} \cdot \mathrm{mm}^{-1}\right]$,

$Y_{i}$ - yield from the irrigated field $\left[\mathrm{kg} \mathrm{ha}^{-1}\right]$, $Y_{r}-$ yield from non-irrigated field $\left[\mathrm{kg} \mathrm{ha}^{-1}\right]$, $E T_{\bar{i}}-$ evapotranspiration measured in the irrigated area $[\mathrm{mm}]$.

$E T_{r}$ - evapotranspiration measured in a non-irrigated area $[\mathrm{mm}]$.

Table 1. Irrigation efficiency indicators (assignment 1-5) for selected plant species from field crops (Bokhtiar et

\begin{tabular}{|c|c|c|c|c|}
\hline Indicator [unit] & \multicolumn{2}{|c|}{ WUE (formula 1) $\left[\mathrm{kg} \cdot \mathrm{ha}^{-1} \cdot \mathrm{mm}^{-1}\right]$} & \multicolumn{2}{|c|}{ WUE (formula 2,3 ) $\left[\mathrm{kg} \cdot \mathrm{ha}^{-1} \cdot \mathrm{mm}^{-1}\right]$} \\
\hline Plant & Radish & White beet & Potato & Cabbage \\
\hline Range of the indicator & $\begin{array}{c}270.9-496.1 \\
\text { (Kang \& Wan 2005) } \\
230.0-312.0 \\
\text { (Bokhtiar et al. 2001) } \\
319.8-434.4 \\
\text { (Bokhtiar et al. 2001) }\end{array}$ & $\begin{array}{c}26.1-46.8 \\
\text { (Ucan \& Gençoğlan } \\
2004 \text { ) } \\
41.5-82.0 \\
\text { (Hassanli et al. 2010) } \\
70.9-115.0 \\
\text { (Topak et al. 2011) } \\
\end{array}$ & $\begin{array}{c}68.0-115.0 \\
\text { (Wang et al. 2011) } \\
65.7-114.3 \\
\text { (Onder et al. 2005) } \\
103.2-131.6 \\
\text { (Kang et al. 2004) }\end{array}$ & $\begin{array}{c}41.1-62.6 \\
\text { (Pawar et al. 2017) } \\
50.2-69.1 \\
\text { (Pawar et al. 2017) } \\
\text { 126.3-137.7 } \\
\text { (Beshir 2017) }\end{array}$ \\
\hline Indicator [unit] & \multicolumn{2}{|c|}{$\mathrm{I}_{\text {WUE }}$ (formula 4) $\left[\mathrm{kg} \cdot \mathrm{ha}^{-1} \cdot \mathrm{mm}^{-1}\right]$} & \multicolumn{2}{|c|}{$\mathrm{ET}_{\text {WUE }}$ (formula 5) $\left[\mathrm{kg} \cdot \mathrm{ha}^{-1} \cdot \mathrm{mm}^{-1}\right]$} \\
\hline Plant & Onion & Carrot & Celery & Maize (grain) \\
\hline Range of the indicator & $\begin{array}{c}4.35-28.1 \\
\text { (Pejic et al. 2014) } \\
13.6-25.5 \\
\text { (Kifle et al. 2017) } \\
69.7-90.2 \\
\text { (Kumar et al. 2007) }\end{array}$ & $\begin{array}{c}181.4-564.2 \\
\text { (Dyśko \& Kaniszewski } \\
2007) \\
169.1-215.2 \\
\text { (Alam et al. 2010) } \\
42.6-336.9 \\
\text { (Baba and Simon 2015) }\end{array}$ & $\begin{array}{c}\text { 190.0-260.0 } \\
\text { (Rekika et al. 2014) } \\
293.8-411.9 \\
\text { (Jun et al. 2016) }\end{array}$ & $\begin{array}{c}11.2-18.0 \\
\text { (Barbieri et al. 2012) } \\
21.0-23.0 \\
\text { (Djaman et al. 2013) } \\
45.7-67.3 \\
\text { (Djaman et al. 2013) }\end{array}$ \\
\hline
\end{tabular}
al. 2001; Kang et al. 2004; Ucan \& Gençoğlan 2004; Kang \& Wan 2005; Onder et al. 2005; Dyśko \& Kaniszewski 2007; Kumar et al. 2007; Alam et al. 2010; Hassanli et al. 2010; Topak et al. 2011; Wang et al. 2011; Barbieri et al. 2012; Djaman et al. 2013; Pejic et al. 2014; Rekika et al. 2014; Baba \& Simon 2015; Wang et al. 2016; Beshir 2017; Kifle et al. 2017; Pawar et al. 2017). 
Formulas $1-5$ show that the yield and total irrigation doses are a key element in the formation of the irrigation efficiency indicator. However, it is worth noting that the values of dose total and irrigation efficiency are not proportional to each other. For example, in the paper by Kang et al. (Kang \& Wan 2005) for potato irrigation, a variable factor was used in the form of different volumes of supplied water (5 variants), ranging from $45 \mathrm{~mm}$ to $153 \mathrm{~mm}$. As a result, the best yielding indices (WUE - formula 1) were obtained for the fields where only 132 and $111 \mathrm{~mm}$ of water column were used during the entire growing season (127.8 and $122.0 \mathrm{~kg} \cdot \mathrm{ha}^{-1} \cdot \mathrm{mm}^{-1}$, respectively). The value of precipitation in all fields was the same. Similar results were achieved in other studies (Tognetti et al. 2003; Dyśko \& Kaniszewski 2007). This relationship does not only apply to the indicators from formulas $1-3$, but also to the $\mathrm{I}_{\mathrm{wUE}}$ indicator (Ünlü et al. 2006). It is also important not to directly compare individual indicators from different studies, even if they are computed by the same dependency. The examples of indicators from dependence $1-5$ are presented in the table 2. It shows that the indicators from the same plant species may differ from each other even by the factor of $2-3$.

\section{ASSESSMENT OF IRRIGATION EFFICIENCY INDICATORS}

The differences included in point 3.1. result from the fact that the indicators of irrigation efficiency in the Water use efficiency group depend on (Figure 3):

- The water dose and application frequency

In the literature, the methods helpful in this respect are measurements of evapotranspiration (Dasila et al. 2017; Chen et al. 2018) or mathematical models (Shang \& Mao 2006; Steppe et al. 2008). However, the largest group are the measurements of the status of soil water, which determine the operation of irrigation systems in terms of dose selection and frequency of irrigation (Shukla et al. 2014; Franz et al. 2015; Peterson et al. 2016; Jama-Rodzeńska et al. 2020; Surya et al. 2020). The partial root zone drying technique is a special and very common case. It consists in wetting only part of the plant's root system in order to provide water to another part of the rhizosphere during the next irrigation (Liu et al. 2006; Sepaskhah \& Ahmadi 2010). Each of the methods is characterized by a different method of determining the dose and frequency, different accuracy, frequency of measurement or the possibility of analysis (only in real time or modeling, for

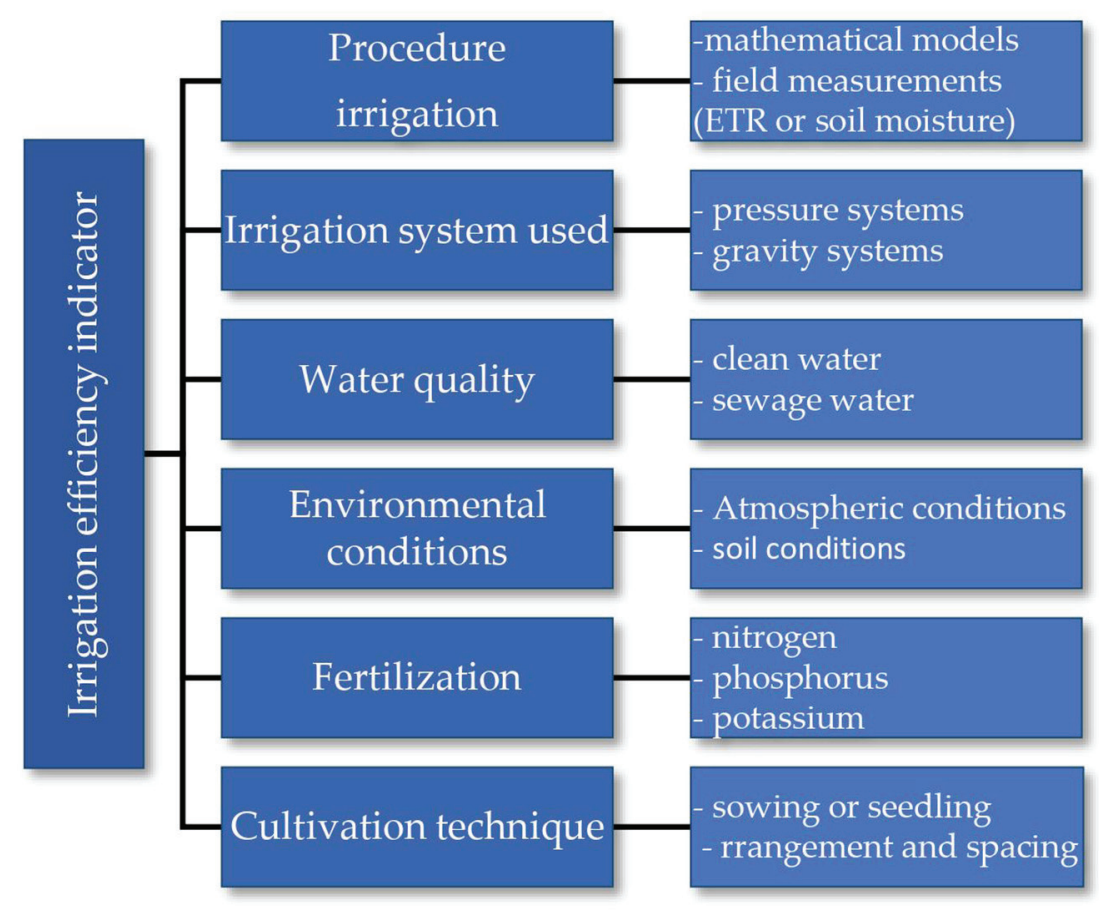

Figure 3. Factors influencing the irrigation efficiency indicator. 
example, the status of soil water in the future). Therefore, it is an important factor in regulating the irrigation efficiency indicator.

- The irrigation system used

The scope of the work efficiency of selected irrigation systems is defined in detail by the aforementioned Irrigation indicator (system performance) efficiency - IE [\%]. For example, for micro-irrigation, the IE indicator is not lower than $85 \%$; for sprinklers, the minimum value is $70 \%$, and for gravity irrigation (e.g., furrow irrigation system) it may be as low as 50\% (Howell 2006; Irmak et al. 2011). However, due to the common parameter of the WUE and IE indicators, which is the volume of water used for irrigation of crops, it should be noted that the type of irrigation system used affects the size of WUE indicators.

\section{- Water quality}

The sources of water for irrigation can be divided into surface (rivers, natural and artificial reservoirs) and underground (drilled and dug wells). Due to the variety of origins, the quality of the water is very important, and it should meet certain standards (Lykhovyd et al. 2019). They concern the chemical composition - dissolved substances such as chlorine, sodium, nitrogen, $\mathrm{pH}$ and the presence of bacteria. For example, salinity can be recorded indirectly, using electrical conductivity- $\mathrm{EC}_{\mathrm{W}}\left[\mathrm{dS} \cdot \mathrm{m}^{-1}\right]$. In the case of potatoes and maize, an increase in $\mathrm{EC}_{\mathrm{W}}$ from 1.1 to $3.9\left[\mathrm{dS} \cdot \mathrm{m}^{-1}\right]$ reduces the yield by $50 \%$ (Bauder et al. 2011). Nevertheless, due to the significant generation of wastewater from domestic and industrial sources, attention was paid to the possibility of their treatment and use for the irrigation purposes. Moreover, this trend will increase in the future (Qadir et al. 2010; AQUASTAT - FAO's global water information system 2014; Jägermeyr et al. 2015).

- Environmental conditions: atmospheric and soil

The environmental conditions (atmospheric and soil) have a direct impact on the regulation of the soil-plant-atmosphere system, which changes over time. The individual components of the balance are, for example: transpiration, evaporation, precipitation or atmospheric sediment (Evaristo et al. 2015; Dawid \& Janik 2018).

The atmospheric conditions are determined by the topography or energy flow (radiation), which affects the circulation of the atmosphere and thermal conditions (Budyko 1969). It all affects the intensity of development of crops (Challinor et al. 2014). Due to the number of factors, it is particularly important to monitor the weather conditions during plant vegetation.

The soil conditions are an environmental factor, the parameters of which can be changed anthropogenically - by mechanical treatments (e.g., plowing). They are designed to maintain the proper structure, which affects evaporation or stimulates the biological development in the soil (Moraru \& Rusu 2010). From the point of view of irrigation, a particularly important role is played by the granulometric composition of the soil material building the soil profile (described by the graining curve) (Skaggs et al. 2001). The particle size distribution, in turn, affects the nature of the $\mathrm{pF}$ curve, showing the relationship between the soil suction force and its moisture (Fredlund et al. 2002; Rajkai et al. 2004; Vereecken et al. 2010). The characteristic points of the retention curve are humidity, for which the suction force of the soil assumes the $\mathrm{pF}$ value in the range $2.0-2.85$ [-]. It is a reserve of water that remains in the soil profile after gravity drainage and is available to plants (Walczak et al. 2006). For example, in sands, this reserve occurs for the volumetric humidity in the range of $7.5-15 \%$, which means that crops should be irrigated frequently, but with small doses. However, in clay material the situation is different. Retention ranges from 20 to $35 \%$, which means that it should irrigate with larger doses of water and less frequently(van Genuchten 1980; OECD 2012). When adjusting the water doses based on field measurements (soil water status), there is a direct impact of the type of soil on the total water volume applied during the entire growing season (Pardossi et al. 2009).

\section{- Fertilization}

The purpose of fertilization includes optimization of the concentration of nutrients in the soil, improvement of chemical $(\mathrm{pH})$, physical (structure improvement) and biological properties (Wang et al. 2011). The compounds containing nitrogen, phosphorus and potassium are the basis of many nutrients [Rajkaj et al. 2004]. All treatments adjusting the quality of the soil environment are to contribute to obtaining higher yields, but they also carry a risk of negative consequences, e.g., too intensive fertilization results in the leaching of fertilizers into the environment and contamination of groundwater (Prasad 2009; Li et al. 2018). Therefore, it is important to study the effect of 
fertilization, including dose adjustment and fertilization date, on the yield indicators. For example, in the paper by Di Paolo and Rinaldi (Di Paolo \& Rinaldi 2008; Prasad 2009; Li et al. 2018), nitrogen fertilization of maize crops in doses of 0.15 and $30 \mathrm{~g}(\mathrm{~N}) \cdot \mathrm{m}^{-2}$ influenced the WUE indicator (formula 2.3), providing the results of $14.6,20.8$ and $22.3 \mathrm{~kg} \cdot \mathrm{ha}^{-1} \cdot \mathrm{mm}^{-1}$, respectively. On the other hand, dosing phosphorus in variants $0,15,39,45 \mathrm{~kg} \cdot \mathrm{ha}^{-1}$ resulted in a bean yield of $735.5,802.3,877.3$ and $935.3 \mathrm{~kg} \cdot \mathrm{ha}^{-1}$ (Kumar et al. 2007). In turn, it has been proven that potassium fertilization reduces the negative effects of water deficiency on the growth of plants such as wheat, maize or sugar beet (Grzebisz et al. 2013). The research clearly proves that the principles of fertilization should be integrated with the irrigation of crops and have a significant impact on the indicators of irrigation efficiency (De Pascale et al. 2018).

\section{- Cultivation techniques}

The basic techniques in the field of cultivation of field crops mainly concern the preparation of the crop by sowing seeds or from produced seedlings. Sowing seeds involves placing the seed at the recommended depth (Seeiso \& Materechera 2011) while covering it with a layer of earth at a specific time of the growing season (Olesen et al. 2012). The basic condition for sowing seeds is their high germination energy. In turn, the production of seedlings involves the preparation of plant seedlings, even before the field treatments. The seedlings are produced in small seedbeds. This provides us with the possibility of greater control over factors such as light, heat or access to water in the seed germination process. Therefore, a measurable result of growing plants from seedlings is greater yield efficiency (Ugur \& Maden 2015).

Both in the case of sowing seeds and the production of seedlings, the method of plant distribution in the field is also a factor determining the yield efficiency. In the case of sowing, among the arrangement techniques, projection, point, nest, row, and belt-row can be distinguished (Zamir et al. 2013; Jamil et al. 2017). However, with seedlings, they are flat cultivation (row, strip-row), on raised beds (single, double rows, on ridges (single, double rows) (Chattha et al. 2007). Apart from the form of plant arrangement, the spacing between them in the row and in the inter-rows is also important. For example, when growing maize, the row spacing can be between 35 and $70 \mathrm{~cm}$. However, for smaller planting intervals, the success rate is $12 \%$ higher (Barbieri et al. 2012). For sugar beet, row spacing can be 15,20 , $25,30,35 \mathrm{~cm}$ and the best yield is obtained with $15 \mathrm{~cm}$ spacing (Sogut \& Arioglu 2004).

Taking into account all the described conditions that affect the final irrigation efficiency indicator, it should be stated that the more factors (potentially variable) are described in the research, the more reliable this assessment is. Therefore, in order to compare the independent test results, the scope of the work carried out (cultivation techniques, fertilization techniques, irrigation system, irrigation dose adjustment procedures) should be characterized in detail and the environmental conditions during the growing season should be described. Such a description should be detailed, but also synthetic (graphical, tabular). Unfortunately, not all the above-mentioned information can be found in all articles.

\section{EVALUATION OF SELECTED IRRIGATION TECHNIQUES}

Irrigation systems can be divided into gravitational and pressure systems. In the gravitational systems - flood, infiltration or water ascent, the transport of water is caused by the force of gravity. Thus, such solutions can be applied only to a limited extent. Therefore, rational use of water resources is a very important issue (Pokładek et al. 2016). These are natural systems, and the extent of their operation is determined by the land relief and by the distance from the source - water reservoir or water course, which must be characterised by a sufficient intensity of water flow, higher than the minimum acceptable flow. The minimum acceptable flow is the minimum flow that ensures biological continuity. Its value is calculated with the use of methods based on fractions of certain standard parameters of water course, such as flow rate at low or medium water level. Examples of the tools for the calculation of the minimum acceptable flow include the Kostrzewa method, FQ10 flow, and the Tennant method (Wilk \& Grabarczyk 2018). In pressure irrigation systems, the transport of medium is enforced by pressure within a closed network. In this group of systems, sprinkler systems as well as surface and subsurface drip lines can be distinguished. Their correct functioning requires a variety of 
components, such as a source of water in the form of a retention reservoir, a drilled well or a water course, a pumping system, movable, flexible or fixed pipelines, electronic control systems, electromagnetic valves, various kinds of sprinklers or emitters. The diversity and large numbers of necessary elements cause that the limitations in the use of systems of this type are on the user side, and frequently they are economic aspects related with the cost of investment in an irrigation system (Guerrero et al. 2016). Nevertheless, due to the effectiveness and efficiency of operation, only pressure irrigation systems are the object of consideration in this paper.

\section{Sprinkler irrigation}

In sprinkler irrigation, the application of water is effected by means of a system of sprinklers. Water is supplied to the soil profile through its surface, under the force of gravity, i.e. in a manner similar to the natural atmospheric precipitation.

Globally, the contribution of sprinkler irrigations in relation to all techniques of water supply amounted to more than $12 \%$ (35 million ha) in
2011, and in $2015-11 \%$. However, among the pressure irrigation systems it is an extremely popular solution and covers as much as $80 \%$ of the irrigated area (Łuszczyk 2009; Kulkarni 2011). The main cause for such a high demand for sprinkler systems is their diversity, mobility, and structure which ensures ease of design, installation, operation and maintenance, control of irrigation intensity, or automation of the system. One can distinguish several variants of sprinkler irrigation systems. One of the possibilities is the division into mobile (bridge-type, reel), semi-fixed and fixed (with rotary sprinklers) systems, as shown in Figure 4. Sprinkler irrigation systems can be operated under various topographic conditions. An additional positive effect of the use of sprinkler systems is a lowering of the temperature of plants. In a study by (Cavero et al. 2009) it was observed that the decrease of maize leaf temperature as a result of the use of sprinkler irrigation during the day reaches $4-6^{\circ} \mathrm{C}$.

Sprinkler irrigation systems, however, are not perfect. Their fundamental flaw is the fact that the technique of water application causes the appearance of the interception and evaporation

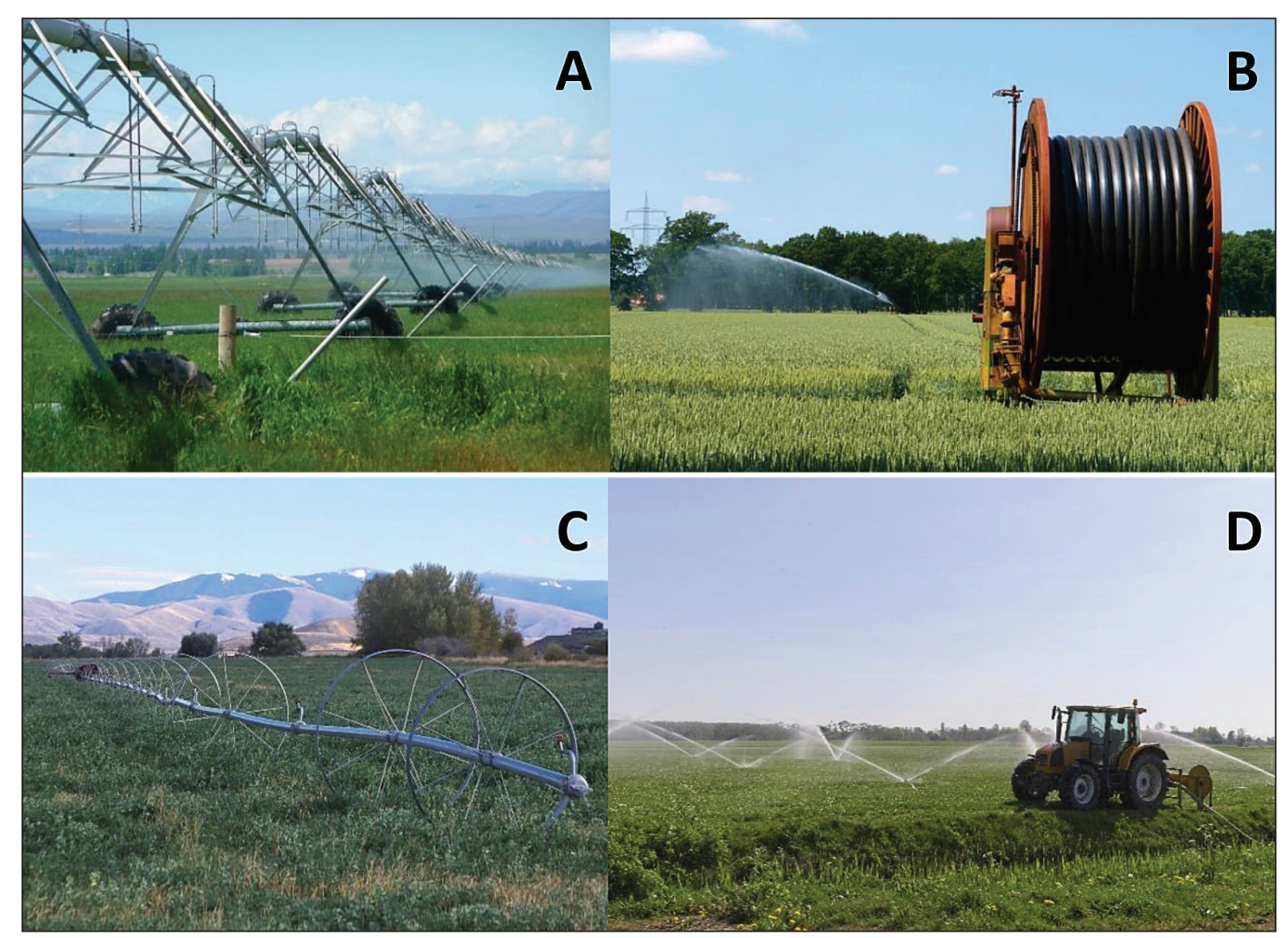

Figure 4. Centre pivot sprinkler (A), reel sprinkler (B), wheel line sprinkler (C) and fixed sprinkler system (D) (Irrigation Agriculture Farming 2020; Irrigation Agriculture Plant 2020; Tractor Water Agricultural Vehicle 2020; Wheel Line Irrigation 2020) 
processes. This results also in a reduction of the amount of supplied water which can be used for the process of transpiration (Cavero et al. 2009). Depending on the type of sprinkler system, the ratio of the volume of water used by the plants to the total volume of water applied by the sprinklers can vary from $65 \%$ (wheel line sprinkler) do $90 \%$ (centre pivot system) (Irmak et al. 2011). That difference results from the distance that a drop of water has to cover between the sprinkler and the soil area with the plant root system. In the case of a water jet, this distance can be as much as tens of metres, and in the case of sprinklers used in centre pivot systems - tens of centimetres. Wind is another factor which can cause a reduction of the amount irrigation water to be used by plants. That factor determines the range and uniformity of water distribution on soil surface during the operation of sprinklers. In a study on the effect of wind on the operation of a fixed sprinkler system, it was demonstrated that the air movement, the velocity of which at the time of irrigation is higher than $2 \mathrm{~m} / \mathrm{s}$, causes such a variation of the depth of wetting of the soil profile that the differences obtained are observable and correspond to the differences in the individual results of yields. A significant correlation $(\mathrm{R} 2=0,916)$ was shown between the uniformity of soil water recharge and the irrigation water distribution uniformity (Dechmi et al. 2003). Irrigation efficiency is also affected by the size of droplets emitted by sprinklers. It has been demonstrated that the droplets with diameters smaller than $1 \mathrm{~mm}$ undergo significant reduction during flight as a result of evaporation. This phenomenon is caused by e.g. high air temperature and intensive solar radiation, but it is believed that the primary cause is the wind (Molle et al. 2012). Another aspect which can have a negative impact on yields is wetting of the aboveground parts of plants. It is a positive phenomenon, but only at small doses of water (several $\mathrm{mm}$ ). In turn, a single irrigation dose varies from 10 to $30 \mathrm{~mm}$, depending on the kind of cultivation and soil type (Rumasz-Rudnicka et al. 2008; Żarski et al. 2013). In the case of irrational management of irrigation schedule, causing an excessive volume of water supplied to the soil, an environment is formed that is conducive to the development of oomycetes, fungi or bacteria - pathogens causing crop plant diseases $(\mathrm{Ca}-$ fé-Filho et al. 2019). An important issue in the operation of sprinkler irrigation systems is their working time. It is determined primarily by the efficiency and number of sprinklers in the system, which results directly from the output of the water source. Due to the specific method of water application, the water sources mentioned must be characterised by a high output which, in the case of the selected manufacturer of reel sprinkler systems, is in the range from 4 to as much as $170 \mathrm{~m}^{3} / \mathrm{h}$ (Wheel line sprinkler 2020). The pressure in the system must also be high. The operation parameters for a specific type of reel sprinkler systems (the same manufacturer) indicate that at an output of $7.2 \mathrm{~m}^{3} / \mathrm{h}$, the pressure must be approx. $4 \mathrm{bar}$, and at the output of ca. $17 \mathrm{~m}^{3} / \mathrm{h}$ as much as 11 bar (Wheel line sprinkler IRTEC 50GBT/230 2020). This enforces the use of pumps in those systems, the operation of which generates the energy consumption that is proportional to the distance and volume of transported liquid. This, in turn, generates operating costs. Łuszczyk determined that the operating costs related to the work of a sprinkler system include energy consumption, labour, amortisation of pumping system, reel and pipelines, and cost of water used (Luszczyk 2009). Apart from these costs, in the course of operation one should also take into account other costs (water-law permits, building permits) as well as investment costs. The latter category includes the construction of a water intake, pumping system, transmission lines, water storage (if needed), and the sprinkler system itself. Kledzik et al. determined that the total cost of an irrigation system for 20 ha of potato amounts to 120 thousand PLN (approx. 26.5 thousand EUR) (Kledzik et al. 2015). Nevertheless, economic analyses indicate that capital investment in sprinkler irrigation system in a majority of cases generates profits, especially with passage of time ( $\mathrm{Rad}$ et al. 2018). IRR is an indicator which permits the assessment of effectiveness of investment projects. It provides the information on the real profit rate of an undertaking, taking into account the change of currency value over time. For example, the financial internal rate of return (IRR) for this type of investment in the case of potato cultivation on light soils is 72.3\% (Lipiński 2015).

\section{Drip lines}

In the system of drip line irrigation, water is applied point-wise onto or under the surface of the soil (Figure 5). The task of drip irrigation is to supply a single plant or a group of plants with water, minimising the evaporation losses which are 
high in the case of sprinkler irrigation systems. In addition, in the case of sprinkler systems, the entire area of cultivation is irrigated, including the spaces between the plants. The characteristic element of drip irrigation systems is a network of flexible tubes with a small diameter. The tubes can be classified as drip tapes ( $\varnothing 17 \mathrm{~mm}$ ) and drip lines (ø 16-20 mm) (Field crops irrigation 2020). The best effects are obtained when the tubes are equipped with drip emitters which reduce the pressure of the outflowing liquid. Owing to this solution, a drip line with pressure compensation can operate already at a pressure of 0.41 bar (Toro Drip line catalog pages 2020). Pressure reduction gives the possibility of irrigation of a considerably larger area, as it allows the laying of longer one-time strings. The number of drip line users grows constantly. It is estimated that in 2030, the combined area of cultivations provided with irrigation systems of this type will be twice as large as in 2000. For comparison, in the case of sprinkler systems, the relation between the area of cultivation in 2030 and 2000 will be slightly greater than 1.5. In the case of other systems, that ratio will be below 1, which means a reduction of the areas irrigated with other techniques. That trend will continue in spite of the high investment costs. As an example, a comparison was made between the costs of irrigation with the use of a sprinkler system and a drip line in the cultivation of beans. The investment costs related with the use of the drip line were twice as high as those in the case of the sprinkler system. Therefore, solutions are being sought to reduce the investment costs. One of such ideas is a reduction of diameters of the water supply lines on the edges of the irrigated area (Chamba et al. 2019) . On the other hand, the operating costs (water + energy) are slightly higher in the case of the sprinkler systems (by 10\%) (Topak \& Yurteri 2017).

The point-wise method of water application directly to the soil space or onto its surface allows numerous benefits. The most important one is a high - relative to other irrigation systems water use efficiency, i.e. the proportion between the water used by plants and the volume of liquid supplied by the irrigation system. This can be as high as $90 \%$ (Sauer et al. 2010). For comparison, in the case of a wheel line sprinkler system it is only $65 \%$. The reason for the high efficiency of the drip line systems is not only the place of water application, but also the technique of its dosage. The emitters, the function of which is the distribution of water, are characterised by the outputs from 1 to 4 l/h. This facilitates the control of moisture in the active horizon of soil which can thus be maintained at the optimum level, adequate to the field water capacity. In

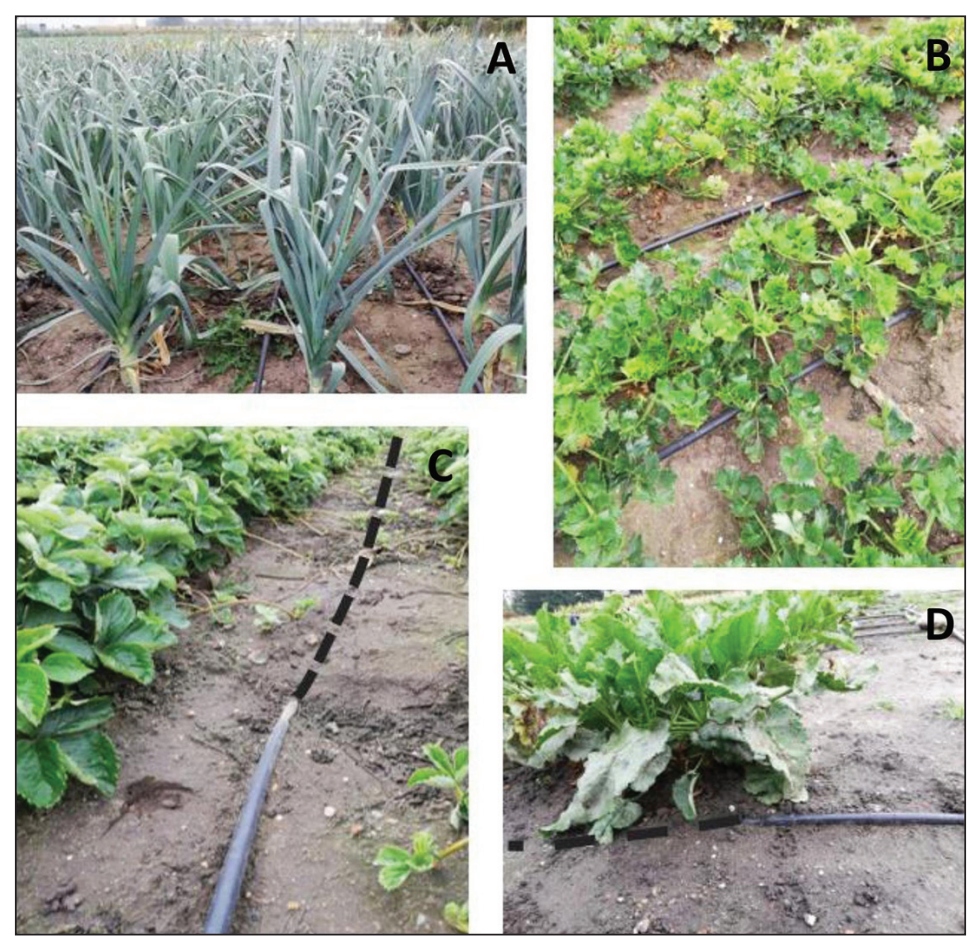

Figure 5. Subsurface drip line (A and B) and surface drip line (C and D) with pressure compensation (own photographs). 
addition, the drip line systems are easier to use in the case of irregular shapes of the irrigated areas and topographic differences (Lamm 2002). The operation of such systems is also easier in the aspect of water dose control (Kumar Sahu $\&$ Behera 2015). This facilitates the regulation of the air-water relations in the soil, causing that with the system of drip irrigations the risk of over-drying the soil and bringing it to the point of plant growth inhibition is minimal (Shock et al. 2013). In the system of drip line irrigation, it is possible to design a mixer which, apart from water, can also apply liquid fertilisers. This causes a significant reduction in their use, as the point-wise application allows eliminating the processes of their leaching to surface water reservoirs (Glińska-Lewczuk 2005; Kasperek et al. 2013; Wiatkowski \& Wiatkowska 2019). In addition, as opposed to the sprinkler irrigation systems, leaves remain dry during the operation of drip line irrigation. Owing to this, the risk of occurrence of diseases of the aboveground parts of plants is notably lower than in the case of sprinklers. On the other hand, it should be noted that there is an increased risk of root diseases (Café-Filho et al. 2019). The fundamental shortcoming of the use of surface drip lines is the cost of purchasing of all elements of the system. The overall schematic of the structure of a drip line irrigation system is similar to that of a sprinkler system. The only difference is the devices the function of which is to apply water to the soil. A drip line system is installed on a specific area for the entire vegetation season. Conversely, sprinkler systems are mobile and can serve areas which are many times larger. In practice, the limiting factor regarding the area served by a system is the accessibility of a water source with sufficient output. In addition, the costs of system operation can increase in a situation of broken or punctured line or blocked emitters. Such breakdowns are the more frequent the more the drip line is exposed to radiation and pests. The application of a drip line irrigation system requires the installation of a drip line before the start of the vegetation season and its removal after the end of the season. In the case of as subsurface drip line, an important issue is the correct determination of the depth of its installation. The optimum depth depends on the crop plant species and on the type of soil on which the cultivation is prepared. For example, in the case of maize cultivation on a sandy soil a higher yield was obtained from fields where the drip line was installed at the depth of $23 \mathrm{~cm}$ compared to the depth of $33 \mathrm{~cm}$. The mean values (from 2 years) of the IWUE index for maize cultivation with drip lines at the depth of $23 \mathrm{~cm}$ was $4.22 \mathrm{~kg} / \mathrm{m}^{3}$, while for an area where the drip line was installed at the depth of $33 \mathrm{~cm}$ the value of IWUE was $2.97 \mathrm{~kg} / \mathrm{m}^{3}$ (Dukes \& Scholberg 2005). Irrigation efficiency was also tested on a silt loam soil. The area for maize cultivation was divided into 5 parts on which the drip lines were placed at depths of $0.2,0.3,0.4,0.5$ and 0.6 metre. The highest yield was obtained from the areas with drip lines installed at the depths of 0.2 and $0.4 \mathrm{~m}$ (17.1 and $17.3 \mathrm{t} / \mathrm{ha}$ ), and the lowest from the area with the drip line at the depth of $0.6 \mathrm{~m}$ (16.5 t/ha). The depth of drip line installation depends also on the development phase of the plant. Incorrect choice of depth may not guarantee the moistening of that part of the soil profile in which seed germination takes place, or it may generate water losses as a result of evaporation (Irmak et al. 2011). Irrigation efficiency can be also improved by using surface mulching (He et al. 2020). In that way, the evaporation process can be eliminated.

\section{SWOT ANALYSIS OF SELECTED IRRIGATION SYSTEMS}

The SWOT analysis is one of the most important methods which allows an orderly presentation of the considerations concerning the estimation of risk of a specific undertaking. The tool has been developed by the employees of the Harvard Business School (Learned et al. 1965). Therefore, SWOT is extensively used in such areas of company functioning as marketing, financial matters, work organisation or production (Learned et al. 1965; Blades 1995; Samejima et al. 2006; Brooks et al. 2014; Pröllochs \& Feuerriegel 2020). Nevertheless, the universal nature of the method allowed its transfer and application in other subject-matter areas, e.g. those related to agriculture. Examples of such an application can be found in the studies on the creation of strategies of development of management of water resources destined for irrigation in a specific region (Chen et al. 2008; Diamantopoulou \& Voudouris 2008)On the basis of such analyses, proposals were formulated for the actions concerning the determination of intensity of ground waters uptake, utilisation 
of treated sewage, application of water-efficient irrigation systems, construction of retention reservoirs, rational policy regarding the use of fertilisers and plant protection agents. An advantage of such analyses is that after preliminary analysis it is possible to precisely identify the issue to be decided on, and to assign importance weights to specific factors. For instance, (Mieldažys et al. 2016) analysed the possibility of using manure as a fertiliser. Every argument entered for the strengths and opportunities was assigned positive values, and those for weaknesses and threats - negative values. The values were obtained owing to independent polls among experts. Next, all the values were added to one another. The obtained total was higher than 0 , which meant that the undertaking was worth the risk. The SWOT acronym comes from the words strengths, weaknesses, opportunities and threats. One should emphasise the fundamental assumption of the method - the aspects of strengths and weaknesses relate to the internal factors concerning the present, while opportunities and threats are external factors, oriented mainly to the future (Pickton \& Wright 1998).

In this study, the SWOT analysis was used to provide an answer to the question: "What irrigation system should be chosen?". Such a decision can be faced by a farmer who wants to achieve higher yields from a given area for the cultivation of one of the crop plants listed in Table 2. The basic assumption of the analysis is that it does not relate to any specific case study. If that were the case, additional important information would be needed on the following:

- size of the area to be irrigated, scatter and fragmentation of fields, soil type, topography of the area;

- availability, prices and quality of water;

- location of the farm in terms of climate zones (precipitation totals, temperatures, duration of vegetation periods);

- market prices relating to investment in irrigation system components, standards ensured by the company involved in the distribution of irrigation equipment (e.g. equipment range on offer, warranty conditions);

- number of available workers, possibility of management of the operation of the irrigation system (automated control, soil moisture measurements);

- market prices for the sale of the produced crops.
In relation to the above, the analysis presented below has a universal character, i.e. the arguments presented here could be placed in at the beginning of any other SWOT analysis. Thus, when addressing a specific case, one can add their own data to the analysis - without the risk of omission of some aspect. Any of the strengths and weaknesses, threats and opportunities that appear in the tables have already been mentioned and described in detail in the paper. Two systems will be analysed: a reel sprinkler with water jet, representing the sprinkler irrigation systems (Table 3) and a drip tape, representing systems from the drip line family of irrigation systems (Table 4). These two types have been chosen for the analysis as they provide the cheapest solutions within their classes. The SWOT analysis is conducted so that some of the arguments relate directly to a given irrigation method, but at the same time can be used for comparison with the other technique. For example, the argument: "low investment cost" in the SWOT table for the reel sprinkler system should be understood as "low investment cost of reel sprinkler, relative to the cost of the drip tape solution".

The SWOT analysis showed a multitude of weaknesses of the reel sprinkler. They are so numerous that they have been divided into categories causally related to the environment (water and cultivation), work organization and economy. The corresponding strengths and weaknesses of the sprinkler system are the ratio of $4: 13$. In the case of opportunities and threats, it is only $1: 2$. However, for the drip line the result is more even (opportunities and threats 3:2, strengths and weaknesses 8:6). However, one should not look at the above-mentioned arguments through the prism of quantity. The influence of individual factors is important, and they always depend on each individual case. Therefore, a weight from 1 to 3 points was added to each argument. On this basis, a graphic has been prepared showing (Figure 6) which of the irrigation methods are characterized by the advantage of strengths and opportunities - it is a form of irrigation in the form of a drip tape. It is also worth noting that the greatest advantage of sprinkler irrigation is its mobility, while in the case of the drip line water saving. These two features should guide the implementation of the concept of innovative irrigation techniques. 
Table 2. SWOT analysis - sprinkler irrigation

\begin{tabular}{|c|c|}
\hline \multicolumn{2}{|c|}{ Reel sprinkler with water jet } \\
\hline Strengths & Weaknesses \\
\hline $\begin{array}{l}\text { - low investment cost (3) } \\
\text { - the device can be used on several areas (3) } \\
\text { - ease of assembly and disassembly of the sprinkler system } \\
\text { (1) number of workers who will operate the system in constant } \\
\text { throughout the vegetation season (1) }\end{array}$ & $\begin{array}{l}\text { ENVIRONMENTAL ASPECTS } \\
\text { - required high pressure and flow rate of available water, } \\
\text { - must be accessible on every area (3) } \\
\text { - water stream deflected by the wind (1) } \\
\text { - increased risk of plant diseases (1) } \\
\text { - evaporation from leaf surface - interception (1) } \\
\text { - risk of damage to plants - water at high pressure strikes the } \\
\text { plants and can damage the aboveground parts (1) } \\
\text { wORK ORGANISATION ASPECTS } \\
\text { - operation and supervision of the system is recommended } \\
\text { - during its effective work time (1) } \\
\text { - if the system is to be used on different areas, its constant } \\
\text { - sprinkler system operation timetable must be set in real } \\
\text { time - it depends on the weather, water requirements of the } \\
\text { plants, and on the soil - this generates a constant problem } \\
\text { which evolves in time (2) } \\
\text { - necessary tool in decision-making on irrigation, the decision } \\
\text { has a highly responsible character (2) } \\
\text { - necessity of operating measurement instruments and } \\
\text { taking decisions on irrigation by employees with suitable } \\
\text { qualifications (1) } \\
\text { - fragmentation and scatter of fields (2) } \\
\text { ECONOMIC ASPECTS } \\
\text { - yield may not be sufficiently high for the rate of return to be } \\
\text { acceptable high (3) }\end{array}$ \\
\hline Opportunities & Threats \\
\hline $\begin{array}{l}\text { - sprinkler system can be used in consecutive vegetation } \\
\text { seasons - also on larger areas (provided the possibilities } \\
\text { related to water source and labour organisation permit) (2) }\end{array}$ & $\begin{array}{l}\text { - risk of impossibility of getting another permit for use of } \\
\text { water from a given source (or its limitation) - this would } \\
\text { reduce the size of irrigated areas (2) } \\
\text { - risk of ineffective use of the irrigation system (1) } \\
\text { - possible occurrence of the problem of adaptation of } \\
\text { employee work time to the operation of the system. } \\
\text { Question arises, should the system work only in daytime } \\
\text { - from the viewpoint of water efficiency this should not be } \\
\text { so, or it can become downright unprofitable - or should the } \\
\text { workers work at night? (1) }\end{array}$ \\
\hline
\end{tabular}

Table 3. SWOT - surface drip line

\begin{tabular}{|c|c|}
\hline \multicolumn{2}{|c|}{ Drip tape } \\
\hline Strengths & Weaknesses \\
\hline $\begin{array}{l}\text { - water-efficiency, water application directly into the zone of } \\
\text { the plant root system - minimisation of evaporation (3) } \\
\text { - } \text { avoidance of interception (1) } \\
\text { - possibility of very precise adaptation of irrigation doses (2) } \\
\text { growthisation in of risk of soil moisture drop to the level of plant } \\
\text { - } 2 \text { precision of irrigation doses = water saving (2) } \\
\text { - system does not need control / can be controlled remotely } \\
\text { (1) } \\
\text { - system can work during the night (1) } \\
\text { possibility of installation of fertiliser dispense - efficient } \\
\text { application of fertilisers (1) }\end{array}$ & $\begin{array}{l}\text { - a given system will be used only on one area (within a } \\
\text { - } \text { dingle irrigated area) in a given vegetation season (3) } \\
\text { - drip tapes get damaged during use (pests, radiation) (1) } \\
\text { - a relatively large is } 2-3 \text { vegetation seasons (2) } \\
\text { installation and dismantling of a drip tape system. For the } \\
\text { rest of the season they are not needed (1) } \\
\text { - necessity of using water filters (1) } \\
\text { - plant root diseases with incorrect use of the system (1) }\end{array}$ \\
\hline Opportunities & Threats \\
\hline $\begin{array}{l}\text { - water-efficient character of the system will allow to reduce } \\
\text { the risk of non-obtainment of permit to use a given source } \\
\text { of water (2) } \\
\text { the drier the vegetation season (less precipitation), the } \\
\text { better yield and higher economic effect can be expected } \\
\text { with rational use of irrigation (2) } \\
\text { Evaporation process can be eliminated using by surface } \\
\text { mulching (1) }\end{array}$ & $\begin{array}{l}\text { - in the case of a vegetation season with a high precipitation } \\
\text { total, the drip line system will not be useful - unnecessary } \\
\text { cost (3) } \\
\text { - a high precipitation amount will cause that the profit per } \\
\text { hectare will be lower - this means a risk that the investment } \\
\text { in the drip line system will result in a relatively reduced level } \\
\text { of profit (2) }\end{array}$ \\
\hline
\end{tabular}




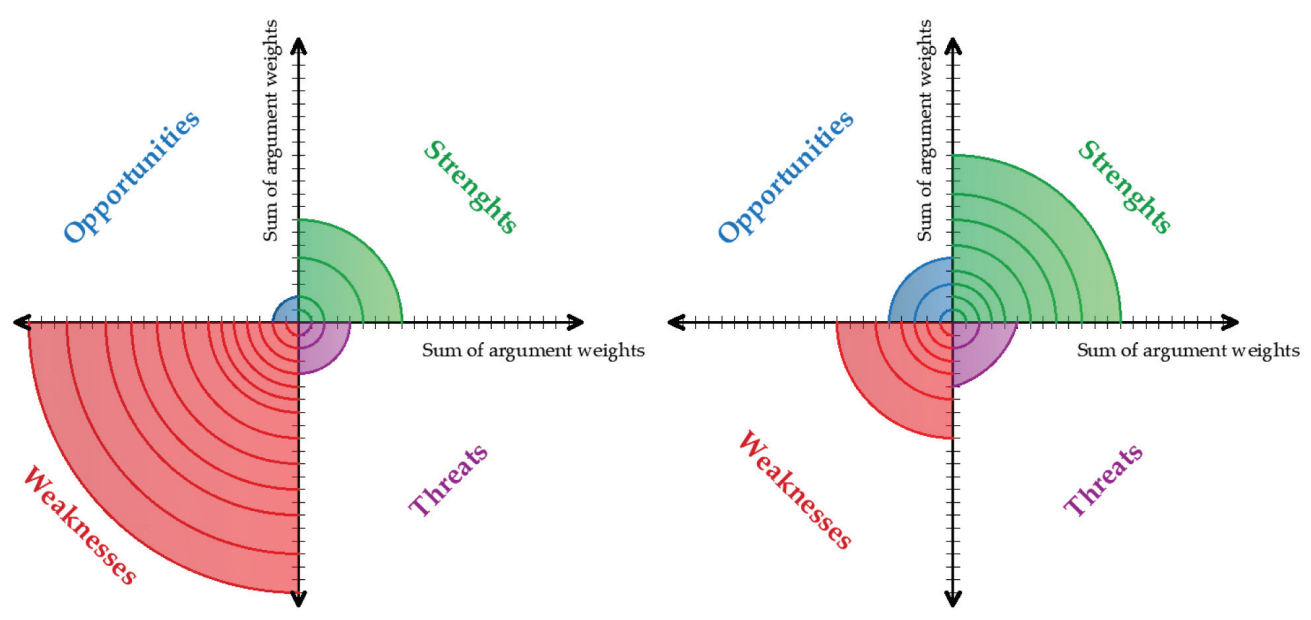

Figure 6. Graphical presentation of the results of the SWOT analysis for a reel sprinkler with a water cannon (on the left) and a drip strip (on the right).

\section{CONCLUSIONS}

There is a phenomenon of a shortage of fresh water on a spatial (world) and time (seasons) scale, it will not decrease due to e.g., the increasing demand for food as a direct result of an increasing number of people. This has the greatest impact on the agricultural sector, being now and in the future the largest freshwater consumer among other sectors of the economy. Currently, agriculture uses over than 5 times more freshwater than industry. It is estimated that in 2100 , the proportion between industry and agriculture will be 1:3. Due to the above, there is a need for changes in the water consumption for irrigation of crops.

First, such changes should be of a cognitive nature. There should be a competent method to assess water use for irrigation under open field conditions. Unfortunately, the multitude of factors influencing the assessment makes this task difficult. All the irrigation efficiency indicators from the WUE group used so far depend on such factors as: the procedure for adjusting the frequency and dose of irrigation, the irrigation system used, water quality, cultivation and fertilization techniques or weather and soil conditions during the growing season. Therefore, regardless of the adopted irrigation efficiency indicator, as much information as possible that may potentially be a variable factor in the research should be specified in a detailed and synthetic form.

Secondly, the changes should concern the prevalence of the use of efficient irrigation techniques. Such a feature is characteristic of pressurized irrigation systems, they include drip lines and selected sprinkler techniques. Sprinkler irrigation systems are currently in the greatest demand. They constitute as much as $80 \%$ of solutions for pressurized irrigation systems. On the other hand, drip irrigation is the method of water delivery that will soon gain the greatest popularity. It is estimated that in 2030, the total area of crops equipped with this type of irrigation systems will be twice as large as in 2000. Therefore, the study also presents a SWOT analysis for two irrigation systems: a reel sprinkler with a water cannon and a drip tape. The analyses are universal and used to assist in deciding which irrigation system to choose. The analysis above showed that the main postulate is the need for the work on innovative irrigation techniques that combine the features of water saving and mobility of the device.

\section{Acknowledgments}

Financed by the National Centre for Research and Development as part of the project "A mobile system for precision injection irrigation and fertilisation meeting the individual requirements of plants". MSINiN - Polish acronym for the project title. Grant number: BIOSTRATEG3/343547/8/ NCBR/2017

\section{REFERENCES}

1. Alam, M. S., Mallik, S. A., Costa, D. J., \& Alam A. 2010. Effect of irrigation on the growth and yield of (Daucus carota ssp. sativus) carrot in hill valley. Bangladesh J Agric Res. 35(2):323-329.

2. Ali M.H., Hoque M.R., Hassan A.A., Khair A. 2007. Effects of deficit irrigation on yield, water productivity, and economic returns of wheat. Agric Water 
Manag. 92(3):151-161.

3. Alyami S.H., Rezgui Y. 2012. Sustainable building assessment tool development approach. Sustain Cities Soc [Internet]. 5(1):52-62. http://dx.doi. org/10.1016/j.scs.2012.05.004

4. AQUASTAT - FAO's global water information system. 2014. Water factsheets. AQUASTAT, FAO's Glob water Inf Syst.:6.

5. AQUASTAT F global water information system. 2014. Irrigated Crops. AQUASTAT website Food Agric Organ United Nations [Internet].: 1. http:// www.fao.org/nr/water/aquastat/infographics/Irrigated_eng.pdf

6. Arnell N.W. 1999. Climate change and global water resources. Glob Environ Chang. 9:31-49.

7. Baba L.Y., Simon G. 2015. The Influence of Irrigation Frequency on Yield and Water Use Efficiency of Carrot. Proc 1st Int Conf Drylands.:47-55.

8. Baligar V.C., Fageria N.K., He Z.L. 2001. Nutrient use efficiency in plants. Commun Soil Sci Plant Anal. 32(7-8):921-950.

9. Barbieri P., Echarte L., della Maggiora A., Sadras V.O., Echeverria H., Andrade F.H. 2012. Maize evapotranspiration and water-use efficiency in response to row spacing. Agron J. 104(4):939-944.

10. Bauder, T. A., Waskom, R. M., Sutherland, P. L., \& Davis JG. 2011. Irrigation Water Quality Criteria. Fact sheet (Colorado State Univ Extension). Crop serie.

11. Beshir S. 2017. Review on Estimation of Crop Water Requirement, Irrigation Frequency and Water Use Efficiency of Cabbage Production. J Geosci Environ Prot. 05(07):59-69.

12. Blades M. 1995. Development of a simple model for analysis of quality. Train Qual [Internet]. 3(1):9-13.

13. Bokhtiar S.M., Karim A.J.M.S., Hossain K.M., Hossain T., Egashira K. 2001. Response of radish to varying levels of irrigation water and fertilizer potassium on clay terrace soil of Bangladesh. Commun Soil Sci Plant Anal. 32(17-18):2979-2991.

14. Boutraa T. 2010. Improvement of water use efficiency in irrigated agriculture: a review. J Agron. 9(1):1-8.

15. Brooks G., Heffner A., Henderson D. 2014. A SWOT Analysis Of Competitive Knowledge From Social Media For A Small Start-Up Business. Rev Bus Inf Syst. 18(1):23-34.

16. Budyko M.I. 1969. The effect of solar radiation variations on the climate of the Earth. Tellus. 21(5):611-619.

17. Burt C.M. 1997. DigitalCommons@ University of Nebraska - Lincoln Irrigation Performance Measures : Efficiency and Uniformity.

18. Café-Filho A.C., Lopes C.A., Rossato M. 2019.
Management of plant disease epidemics with irrigation practices. Irrig Agroecosystems. 123.

19. Cassardo C., Jones JA.A. 2011. Managing Water in a Changing World. Water. 3:618-628.

20. Cavero J., Medina E.T., Puig M., Martínez-Cob A. Sprinkler irrigation changes maize canopy microclimate and crop water status, transpiration, and temperature. Agron J. 101(4).

21. Chai Q., Gan Y., Turner N.C., Zhang R.Z., Yang C., Niu Y., Siddique K.H.M. 2014. Water-saving innovations in Chinese agriculture. 126. 149-201.

22. Chai Q., Gan Y., Zhao C., Xu H.L., Waskom R.M., Niu Y., Siddique K.H.M. 2016. Regulated deficit irrigation for crop production under drought stress. A review. Agron Sustain Dev. 36(1):1-21.

23. Challinor A.J., Watson J., Lobell D.B., Howden S.M., Smith D.R., Chhetri N. 2014. A meta-analysis of crop yield under climate change and adaptation. Nat Clim Chang. 4(4):287-291.

24. Chamba D., Zubelzu S., Juana L. 2019. Energy, cost and uniformity in the design of drip irrigation systems. Biosyst Eng. 178(2013):200-218.

25. Chateau J., Dellink R., Lanzi E. 2014. An Overview of the OECD ENV-Linkages Model: Version 3.

26. Chattha M.U., Ali A., Bilal M. 2007. Influence of Planting Techniques on Growth and Yield of Spring Planted Sugarcane ( Saccharum Officinarum L .). Pak J Agri Sci. 44(3):3-7.

27. Chen D., Chen J., Chen X.M., Li R., HU W. 2008. Study on Development Strategy of Administrative Organization of Irrigation District Based on SWOT Analysis. Water Sav Irrig. 6.

28. Chen Y., Marek G.W., Marek T.H., Brauer D.K., Srinivasan R. 2018. Improving SWAT auto-irrigation functions for simulating agricultural irrigation management using long-term lysimeter field data. Environ Model Softw. 99:25-38.

29. Courtland R. 2008. Enough water to go round? Nature.

30. Dasila B., Singh V., Kushwaha H., Srivastava A., Ram S. 2017. Water use efficiency and yield of cowpea and nutrient loss in lysimeter experiment under varying water table depth, irrigation schedules and irrigation method. SAARC J Agric. 14(2):46-55.

31. Dawid M., Janik G. 2018. Atmospheric water infiltration intensity in non-rainfall periods under conditionsof varied soil moisture. Int Agrophysics. 32(3):305-312.

32. Dechmi F., Playán E., Cavero J., Faci J.M., Martínez-Cob A. 2003. Wind effects on solid set sprinkler irrigation depth and yield of maize [Zea mays]. Irrig Sci. 22(2):67-77.

33. Denisov Y.M., Sergeev A.I., Bezborodov G.A., Bezborodov Y.G. 2002. Moisture evaporation from bare 
soils. Irrig Drain Syst. 16(3):175-182.

34. Diamantopoulou P., Voudouris K. 2008. Optimization of water resources management using SWOT analysis: The case of Zakynthos Island, Ionian Sea, Greece. Environ Geol. 54(1):197-211.

35. Djaman K., Irmak S., Rathje W.R., Martin D.L., Eisenhauer D.E. 2013. Maize evapotranspiration, yield production functions, biomass, grain yield, harvest index, and yield response factors under full and limited irrigation. Trans ASABE. 56(2):373-393.

36. Dudu H., Chumi S. 2008. Economics of Irrigation Water Management. (March).

37. Dukes M. D., Scholberg J. M. 2005. Soil Moisture Controlled Subsurface Drip Irrigation on Sandy Soils. Appl Eng Agric. 21(1):89-101.

38. Dunage V.S., Balakrishnan P., Patil M.G. 2009. Water use efficiency and economics of tomato using drip irrigation under netthouse conditions. Karnataka J Agric Sci. 22(1):133-136.

39. Dyśko J., Kaniszewski S. 2007. Effect of drip irrigation, $\mathrm{n}$-fertigation and cultivation methods on the yield and quality of carrot. Veg Crop Res Bull. 67(2000):25-33.

40. Eales A., Clifford M. 2013. Sustainability and Engineering. University of Nottingham.

41. Elgaali E., Garcia L.A., Ojima D.S. 2007. High resolution modeling of the regional impacts of climate change on irrigation water demand. Clim Change. 84(3-4):441-461.

42. Eliasson Å., Faurès J-M., Frenken K., Hoogeveen J. 2005. Aquastat - Getting to grips eith water information for agriculture.

43. Eurostat Statistics Explained. 2020. Water statistics [Internet]. [accessed 2020 Jun 10]. https:// ec.europa.eu/eurostat/statistics-explained/index. php/Water_statistics\#Water_uses

44. Evaristo J., Jasechko S., McDonnell J.J. 2015. Global separation of plant transpiration from groundwater and streamflow. Nature. 525(7567):91-94.

45. Field crops irrigation. 2020. Tanake [Internet]. [accessed 2021 Jan 20]. https://nts.tanake.com.pl/ Nawadnianie-upraw-polowych

46. Foley J.A., DeFries R., Asner G.P., Barford C., Bonan G., Carpenter S.R., Chapin F.S., Coe M.T., Daily G.C., Gibbs H.K., et al. 2005. Global consequences of land use. Science (80- ). 309(5734):570-574.

47. Franz T.E., Wang T., Avery W., Finkenbiner C., Brocca L. 2015. for Multiscale Real-Time Monitoring. (May):1-8.

48. Fredlund M.D., Wilson G.W., Fredlund D.G. 2002. Use of the grain-size distribution for estimation of the soil-water characteristic curve. Can Geotech J. 39(5):1103-1117.

49. Gerten D., Heinke J., Hoff H., Biemans H., Fader
M., Waha K. 2011. Global water availability and requirements for future food production. J Hydrometeorol. 12(5):885-899.

50. Gleick P.H. 2003. Global Freshwater Resources: Soft-Path Solutions for the 21st Century. Science (80- ). 302(5650):1524-1528.

51. Glińska-Lewczuk K. 2005. Oxbow lakes as biogeochemical filters for nutrient outflow from agricultural areas. IAHS-AISH Publ.(294):55-65.

52. GRID-Arendal. 2009. Water Scarcity Index [Internet]. [accessed 2021 Jan 20]. https://www.grida. no/resources $/ 5586$ ?fbclid=IwAR1Di-4CUrJGtkKgO7DPOZ0ieW2oCcKsirNb2Wvb9xHsJlhaHVq7oQMkXVY

53. Grzebisz W., Gransee A., Szczepaniak W., Diatta J. 2013. The effects of potassium fertilization on water-use efficiency in crop plants. J Plant Nutr Soil Sci. 176(3):355-374.

54. Guerrero B., Amosson S., Almas L., Marek T., Porter D. 2016. Economic Feasibility of Converting Center Pivot Irrigation to Subsurface Drip Irrigation. J ASFMRA.:77-88.

55. Hamdy A., Lamaddalena N., Shatanawi M., Todorovic M., Bogliotti C., Albrizio R. 2007. Water use efficiency in irrigated agriculture: An analytical review. Proc 4th WASAMED Work Water Use Effic Water Product. 19:9-19.

56. Hassanli A.M., Ahmadirad S., Beecham S.. 2010. Evaluation of the influence of irrigation methods and water quality on sugar beet yield and water use efficiency. Agric Water Manag. 97(2):357-362.

57. He Z., Shang X., Zhang T. 2020. Study on water saving potential and net profit of Zea mays L.: The role of surface mulching with micro-spray irrigation. Appl Sci. 10(1).

58. Hoekstra A.Y., Mekonnen M.M. 2012. The water footprint of humanity. Proc Natl Acad Sci U S A. 109(9):3232-3237.

59. Howell T.A. 2006. Challenges in increasing water use efficiency in irrigated agriculture. Int Symp Water L Manag Sustain Irrig Agric. 5746(806):11.

60. Huntington T.G. 2006. Evidence for intensification of the global water cycle: Review and synthesis. J Hydrol. 319(1-4):83-95.

61. Irmak S., Odhiambo L.O., Kranz W.L., Eisenhauer D.E. 2011. Irrigation Efficiency and Uniformity, and Crop Water Use Efficiency. Biol Syst Eng.

62. Irrigation Agriculture Farming. 2020. Pixabay [Internet]. [accessed 2021 Jan 20]. https://pixabay. com/photos/irrigation-agriculture-farming-403371/

63. Irrigation Agriculture Plant. 2020. Pixabay [Internet]. [accessed 2021 Jan 20]. https://pixabay.com/ photos/irrigation-agriculture-plant-green-4483147/

64. Jackson, R. B., Carpenter, S. R., Dahm, C. N., 
McKnight, D. M., Naiman, R. J., Postel, S. L., Running S.W. 2001. Issues in Ecology. WATER A Chang WORLD. 11(4):1027-1045.

65. Jägermeyr J., Gerten D., Heinke J., Schaphoff S., Kummu M., \& Lucht W. 2015. Water savings potentials of irrigation systems: dynamic global simulation. Hydrol Earth Syst Sci Discuss. 19(1):1-32.

66. Jama-Rodzeńska A., Walczak A., AdamczewskaSowińska K., Janik G., Kłosowicz I., Głąb L., Sowiński J., Chen X., Pęczkowski G. 2020. Influence of variation in the volumetric moisture content of the substrate on irrigation efficiency in early potato varieties. PLoS One. 15(4).

67. Jamil M., Hussain S.S., Qureshi M.A., Mehdi S.M., Nawaz M.Q. 2017. Impact of sowing techniques and nitrogen fertilization on castor bean yield in salt affected soils. J Anim Plant Sci. 27(2):451-456.

68. Jun, Y., Xiaojuan, L., Yan, W., Zhang, Y., \& Zhengxiang W. 2016. Effects of Different Irrigation Amounts on Water Consumption and Water Use Efficiency of Dripirrigated Celery. Agric Sci Technol. 17(9).

69. Kang Y., Wan S.. 2005. Effect of soil water potential on radish (Raphanus sativus L.) growth and water use under drip irrigation. Sci Hortic (Amsterdam). 106(3):275-292.

70. Kang Y., Wang F.X., Liu H.J., Yuan B.Z. 2004. Potato evapotranspiration and yield under different drip irrigation regimes. Irrig Sci. 23(3):133-143.

71. Kasperek R., Mokwa M., Wiatkowski M.. 2013. Modelling of pollution transport with sediment on the example of the Widawa river. Arch Environ Prot. 39(2):29-43.

72. Kaya Ç.I., Yazar A., Sezen S.M. 2015. SALTMED Model Performance on Simulation of Soil Moisture and Crop Yield for Quinoa Irrigated Using Different Irrigation Systems, Irrigation Strategies and Water Qualities in Turkey. Agric Agric Sci Procedia. 4:108-118.

73. Kifle M., Gebremicael T.G., Girmay A., Gebremedihin T. 2017. Effect of surge flow and alternate irrigation on the irrigation efficiency and water productivity of onion in the semi-arid areas of North Ethiopia. Agric Water Manag. 187(June):69-76.

74. Kim H., Jeong H., Jeon J., Bae S. 2016. Effects of irrigation with saline water on crop growth and yield in greenhouse cultivation. Water (Switzerland). 8(4):1-9.

75. Kledzik R., Kropkowski M., Rzekanowski C., Żarski J., Technologiczno-Przyrodniczy U, Śniadeckich W Bydgoszczy JJ. 2015. Economic evaluation of the efficiency of irrigation in selected crops. 51:291-303.

76. Kucharik C.J., Foley J.A., Délire C., Fisher V.A., Coe M.T., Lenters J.D., Young-Moiling C., Ramankutty N., Norman J.M., Gower S.T. 2000. Testing the performance of a dynamic global ecosystem model:
Water balance, carbon balance, and vegetation structure. Global Biogeochem Cycles. 14(3):795-825.

77. Kulkarni S. 2011. Innovative Technologies for Water Saving in Irrigated Agriculture. Int J Water Resour Arid Environ. 1(3):226-231.

78. Kumar S., Imtiyaz M., Kumar A., Singh R. 2007. Response of onion (Allium cepa L.) to different levels of irrigation water. Agric Water Manag. 89(1-2):161-166.

79. Kumar Sahu C., Behera P. 2015. A low cost smart irrigation control system. 2nd Int Conf Electron Commun Syst ICECS 2015.(Icecs):1146-1151.

80. Kuśnierz M., Burszta-Adamiak E., Janik G. 2018. Supply of water for irrigation of farmlands in the new organizational and legal conditions. (4):1057-1070.

81. Lamm F.R. 2002. Advantages and disadvantages of subsurface drip irrigation. In: Int Meet Adv Drip/ Micro Irrig. Puerto de La Cruz, Tenerife, Canary Islands.

82. Land and water. 2020. Food Agric Organ United Nations [Internet]. [accessed 2021 Jan 20]. http://www. fao.org/land-water/outreach/graphs-and-maps/en/

83. Learned A., Christensen C., Andrews R.S., Guth D. 1965. Business Policy. Text Cases (Homewood, Illinois Irwin).

84. Li Y., Li J., Gao L., Tian Y. 2018. Irrigation has more influence than fertilization on leaching water quality and the potential environmental risk in excessively fertilized vegetable soils. PLoS One. 13(9):1-23.

85. Lipiński J. 2015. Efektywność Ekonomiczno-finansowa deszczownianego nawadniania ziemniaków jadalnych na glebach lekkich w warunkach produkcyjnego gospodarstwa rolnego. Water-environmentrural areas.(51):61-73.

86. Liu C., Zhang X., Zhang Y. 2002. Determination of daily evaporation and evapotranspiration of winter wheat and maize by large-scale weighing lysimeter and micro-lysimeter. Agric For Meteorol. 111(2):109-120.

87. Liu F., Shahnazari A., Andersen M.N., Jacobsen S.E., Jensen C.R. 2006. Effects of deficit irrigation (DI) and partial root drying (PRD) on gas exchange, biomass partitioning, and water use efficiency in potato. Sci Hortic (Amsterdam). 109(2):113-117.

88. Luszczyk K. 2009. Expenditures for irrigation of plantations of commodity crops. Infrastruct Ecol Rural areas.(6):303-315.

89. Lykhovyd P., Dementiieva O., Lavrenko S., Lavrenko N. 2019. Agro-environmental evaluation of irrigation water from different sources, together with drainage and escape water of rice irrigation systems, according to its impact on Maize (Zea mays L.). J Ecol Eng. 20(2):1-7.

90. Mieldažys R., Jotautienė E., Pocius A., Jasinskas A. 
2016. Analysis of organic agricultural waste usage for fertilizer production. Agron Res. 14(1):143-149.

91. Molle B., Tomas S., Hendawi M., Granier J. 2012. Evaporation and wind drift losses during sprinkler irrigation influenced by droplet size distribution. Irrig Drain. 61(2):240-250.

92. Moraru P.I., Rusu T. 2010. Soil tillage conservation and its effect on soil organic matter, water management and carbon sequestration. J Food, Agric Environ. 8(3-4 PART 1):309-312.

93. Nair S., Johnson J., Wang C. 2013. Efficiency of irrigation water use: A review from the perspectives of multiple disciplines. Agron J. 105(2):351-363.

94. OECD. 2012. Environmental outlook to 2050 - key findings on biodiversity. OECD Environ Outlook to 2050 Consequences Ina.(March): 7.

95. Oki T., Kanae S. 2006. Global hydrological cycles and world water resources. Science (80- ). 313(5790):1068-1072.

96. Olesen J.E., Børgesen C.D., Elsgaard L., Palosuo T., Rötter R.P., Skjelvåg A.O., Peltonen-Sainio P., Börjesson T., Trnka M., Ewert F., et al. 2012. Changes in time of sowing, flowering and maturity of cereals in Europe under climate change. Food Addit Contam - Part A Chem Anal Control Expo Risk Assess. 29(10):1527-1542.

97. Onder S., Caliskan M.E., Onder D., Caliskan S. 2005. Different irrigation methods and water stress effects on potato yield and yield components. Agric Water Manag. 73(1):73-86.

98. Di Paolo E., Rinaldi M. 2008. Yield response of corn to irrigation and nitrogen fertilization in a Mediterranean environment. F Crop Res. 105(3):202-210.

99. Pardossi A., Incrocci L., Incrocci G., Malorgio F., Battista P., Bacci L., Rapi B., Marzialetti P., Hemming J., Balendonck J. 2009. Root Zone Sensors for Irrigation Management in Intensive Agriculture. Sensors. 9(4):2809-2835.

100. De Pascale S., Maggio A., Ruggiero C., Barbieri G. 2003. Growth, water relations, and ion content of field-grown celery [Apium graveolens L. var. dulce (Mill.) Pers.] under saline irrigation. J Am Soc Hortic Sci. 128(1):136-143.

101. De Pascale S., Rouphael Y., Gallardo M., Thompson R.B. 2018. Water and fertilization management of vegetables: State of art and future challenges. Eur J Hortic Sci. 83(5):306-318.

102. Pawar G.S., Kale M.U., Lokhande J.N. 2017. Response of AquaCrop Model to Different Irrigation Schedules for Irrigated Cabbage. Agric Res. 6(1):73-81.

103. Pejic B., Gajic B., Bosnjak D., Stricevic R., Mackic K., Kresovic B. 2014. Effects of water stress on water use and yield of onion. Bulg J Agric Sci. 20(2):297-302.
104. Peterson A.M., Helgason W.D., Ireson A.M. 2016. Estimating field-scale root zone soil moisture using the cosmic-ray neutron probe. Hydrol Earth Syst Sci. 20(4):1373-1385.

105. Pickton D.W., Wright S. 1998. What's swot in strategic analysis? Strateg Chang. 7(2):101-109.

106. Pimentel D., Berger B., Filiberto D., Newton M., Wolfe B., Karabinakis E., Clark S., Poon E., Abbett E., Nandagopal S. 2007. Water resources: Agricultural and environmental issues. Food, Energy, Soc Third Ed. 54(10):183-200.

107. Pokładek R., Kowalczyk T., Orzepowski W., Żmuda R. 2016. Retencyjność gleb w okresie wegetacyjnym na przykładzie obiektu Samotwór. Infrastrucuture Ecol Rural areas. 1(I):33-44.

108. Prasad R. 2009. Efficient fertilizer use : The key to food security and better environment Review / Synthesis Efficient fertilizer use : The key to food security and better environment. J Trop Agric. 47(January):1-17.

109. Production of agricultural and horticultural crops in 2018. 2019. Stat Pol [Internet]. [accessed 2001 Jan 20]. https://bdl.stat.gov.pl/BDL/dane/podgrup/ temat

110. Pröllochs N., Feuerriegel S. 2020. Business analytics for strategic management: Identifying and assessing corporate challenges via topic modeling. Inf Manag. 57(1):103070.

111. PURE-H2O. 2021. Economic Characteristics of Water [Internet]. [accessed 2021 Jan 20]. https:// pure-h2o-learning.eu/units-of-leatning-outcomes/ ulo5/362-chaptr-11-economics-of-drinkingwater? showall $=\&$ start $=3$

112. Qadir M., Wichelns D., Raschid-Sally L., McCornick P.G., Drechsel P., Bahri A., Minhas P.S. 2010. The challenges of wastewater irrigation in developing countries. Agric Water Manag. 97(4):561-568.

113. Rad S., Gan L., Chen X., You S., Huang L., Su S., Taha M.R. 2018. Sustainable water resources using corner pivot lateral, A novel sprinkler irrigation system layout for small scale farms. Appl Sci. 8(12).

114. Rajkai K., Kabos S., Van Genuchten M.T.. 2004. Estimating the water retention curve from soil properties: Comparison of linear, nonlinear and concomitant variable methods. Soil Tillage Res. 79(2 SPEC.ISS.):145-152.

115. Rekika D., Caron J., Rancourt G.T., Lafond J.A., Gumiere S.J., Jenni S., Gosselin A. 2014. Optimal irrigation for onion and celery production and spinach seed germination in Histosols. Agron J. 106(3):981-994.

116. Rockström J., Falkenmark M., Karlberg L., Hoff H., Rost S., Gerten D. 2009. Future water 
availability for global food production: The potential of green water for increasing resilience to global change. Water Resour Res. 45(7):1-16.

117. Rockström J., Karlberg L., Wani S.P., Barron J., Hatibu N., Oweis T., Bruggeman A., Farahani J., Qiang Z. 2010. Managing water in rainfed agriculture-The need for a paradigm shift. Agric Water Manag. 97(4):543-550.

118. Rosegrant, M. W., Cai X. and Cline S.A. 2002. World water and food to 2025: dealing with scarcity. Intl Food Policy Res Inst.

119. Rumasz-Rudnicka E., Koszański Z., Woroniecki T.K. 2008. Effect of irrigation on some vegetables. Acta Agrophysica. 11(2):509-517.

120. Salvatierra-Bellido B., Montero-Martínez J., Pérez-Urrestarazu L. 2018. Development of an automatic test bench to assess sprinkler irrigation uniformity in different wind conditions. Comput Electron Agric. 151(June):31-40.

121. Samejima M., Shimizu Y., Akiyoshi M., Komoda N. 2006. SWOT analysis support tool for verification of business strategy. 2006 IEEE Int Conf Comput Cybern ICCC.(September 2006).

122. Sarkar N., Ghosh U., Biswas R.K. 2018. Effect of drip irrigation on yield and water use efficiency of summer rice cultivation in pots. J Pharmacogn Phytochem. 7(December 2017):37-40.

123. Sauer T., Havlík P., Schneider U.A., Schmid E., Kindermann G., Obersteiner M. 2010. Agriculture and resource availability in a changing world: The role of irrigation. Water Resour Res. 46(6):1-12.

124. Seeiso, T. M., \& Materechera S.A. 2011. Effects of Seed Sowing Depth on Emergence and Early Seedling Development of Two African Indigenous Leafy Vegetables. Life Sci J. 8(2):12-17.

125. Sepaskhah A.R., Ahmadi SH. 2010. A review on partial root-zone drying irrigation. Int J Plant Prod. 4(4):241-258.

126. Shang, S., \& Mao X. 2006. Application of a simulation based optimization model for winter wheat irrigation scheduling in North China. Agric Water Manag. 85(3):314-322.

127. Shiklomanov I.A. 2000. Appraisal and Assessment of world water resources. Water Int. 25(1):11-32.

128. Shirazi M.M.A., Kargari A. 2015. A review on applications of membrane distillation (MD) process for wastewater treatment. J Membr Sci Res. 1(3):101-112.

129. Shock C., Flock R., Eldredge E., Pereira A., Jensen L. 2013. Successful Potato Irrigation Scheduling. Sustain Agric Tech.

130. Shukla A., Panchal H., Mishra M., Patel P.R., Srivastava H.S., Patel P., Shukla A.K. 2014. Soil Moisture Estimation using Gravimetric Technique and
FDR Probe Technique : A Comparative Analysis. (July 2015):89-92.

131. Singh A., Aggarwal N., Aulakh G.S., Hundal R.K. 2012. Ways to Maximize the Water Use Efficiency in Field Crops - A review. Greener J Agric Sci. 2(4):108-129.

132. Skaggs, T. H., Arya, L. M., Shouse, P. J., \& Mohanty BP. 2001. Estimating particle-size distribution from limited soil texture data. Soil Sci Soc Am J. 65(4):1038-1044.

133. Sogut, T., \& Arioglu H. 2004. Plant density and sowing date effects on sugarbeet yield and quality. J Agron.

134. Steppe K., De Pauw D.J.W., Lemeur R. 2008. A step towards new irrigation scheduling strategies using plant-based measurements and mathematical modelling. Irrig Sci. 26(6):505-517.

135. Surya S.G., Yuvaraja .S, Varrla E., Baghini M.S., Palaparthy V.S., Salama K.N. 2020. An in-field integrated capacitive sensor for rapid detection and quantification of soil moisture. Sensors Actuators, B Chem. 321(April).

136. The Source - International Water Association. 2015. How will the UN measure and monitor the Sustainable Development Goal 6 for Water \& Sanitation? [Internet]. [accessed 2021 Jan 20]. https:// www.thesourcemagazine.org/will-un-measuremonitor-sustainable-development-goal-6-watersanitation/

137. Tognetti R., Palladino M., Minnocci A., Delfine S., Alvino A. 2003. The response of sugar beet to drip and low-pressure sprinkler irrigation in southern Italy. Agric Water Manag. 60(2):135-155.

138. Topak R., Süheri S., Acar B. 2011. Effect of different drip irrigation regimes on sugar beet (Beta vulgaris L.) yield, quality and water use efficiency in Middle Anatolian, Turkey. Irrig Sci. 29(1):79-89.

139. Topak R., Yurteri E. 2017. Economical Analysis of Sprinkler and Drip Irrigated-Dry Bean Production. Selcuk J Agric Food Sci. 31(2):68-75.

140. Toro Drip line catalog pages. 2020. Tanake [Internet]. [accessed 2021 Jan 20]. https://nts.tanake. com.pl/uploads/file/NTS/Zastosowania_nawadnianie_upraw_polowych/Katalog_linie_kroplujace. pdf

141. Tractor Water Agricultural Vehicle. 2020. Pixabay [Internet]. [accessed 2021 Jan 20]. https://pixabay.com/photos/ tractor-water-agricultural-vehicle-5096163/

142. Ucan K., Gençoğlan C. 2004. The effect of water deficit on yield and yield components of sugar beet. Turkish J Agric For. 28(3):163-172.

143. Ugur A., Maden H.A. 2015. Sowing and planting period on yield and ear quality of sweet corn (Zea mays 1. Var. Saccharata). Ciência e Agrotecnologia. 


$$
\text { 39(1):48-57. }
$$

144. Ullah H., Santiago-Arenas R., Ferdous Z., Attia A., Datta A. 2019. Improving water use efficiency, nitrogen use efficiency, and radiation use efficiency in field crops under drought stress: A review. Adv Agron. 156(March):109-157.

145. Unies N. 2009. Water in a changing world. The United Nations World Water Development Report 3. Paris, France.

146. United F and AO of the. 2020. Aquastat database. Food Agric Organ United [Internet]. [accessed 2021 Jan 20]. http://www.fao.org/nr/water/aquastat/data/query/results.html?regionQuery=true\& yearGrouping=SURVEY\&showCodes=false\&ye arRange. from Year $=1958 \&$ yearRange. to Year $=20$ $17 \&$ varGrpIds $=4250 \% 2 \mathrm{C} 4251 \% 2 \mathrm{C} 4252 \% 2 \mathrm{C} 42$ $53 \% 2 \mathrm{C} 4257 \& \mathrm{cntIds}=\& \mathrm{regIds}=9805 \% 2 \mathrm{C} 9806 \%$ 2C9807\%2C9808\%2C9809\&edit

147. Ünlü M., Kanber R., Şenyigit U., Onaran H., Diker K. 2006. Trickle and sprinkler irrigation of potato (Solanum tuberosum L.) in the Middle Anatolian Region in Turkey. Agric Water Manag. 79(1):43-71.

148. Van Genuchten M. Th.. 1980. A closed-form equation for predicting the hydraulic conductivity of unsaturated soils. Soil Sci Soc Am J. 44:892-898.

149. Vanham D., Bidoglio G. 2013. A review on the indicator water footprint for the EU28. Ecol Indic. 26(2013):61-75.

150. Vereecken H., Weynants M., Javaux M., Pachepsky Y., Schaap M.G., van Genuchten M.T. 2010. Using Pedotransfer Functions to Estimate the van Genuchten-Mualem Soil Hydraulic Properties: A Review. Vadose Zo J. 9(4):795-820.

151. Vörösmarty C.J., Green P., Salisbury J., Lammers R.B. 2000. Global water resources: Vulnerability from climate change and population growth. Science. 289(5477):284-288.

152. Wada Y., Bierkens M.F.P. 2014. Sustainability of global water use: Past reconstruction and future projections. Environ Res Lett. 9(10).

153. Walczak R.T., Moreno F., Sławiński C., Fernandez E., Arrue J.L. 2006. Modeling of soil water retention curve using soil solid phase parameters. J Hydrol. 329(3-4):527-533.

154. Wang F.X., Wu X.X., Shock C.C., Chu L.Y., Gu X.X., Xue X. 2011. Effects of drip irrigation regimes on potato tuber yield and quality under plastic mulch in arid Northwestern China. F Crop Res. 122(1):78-84.

155. Wheel Line Irrigation. 2020. Commons, Wikimedia [Internet]. [accessed 2021 Jan 20]. https://commons.wikimedia.org/wiki/
File:WheelLineIrrigation.JPG

156. Wheel line sprinkler. 2020. ŁUKOMET [Internet]. [accessed 2021 Jan 20]. https://www.lukomet. $\mathrm{pl} / \mathrm{g}$-szpulowe-deszczownie-c649

157. Wheel line sprinkler IRTEC 50GBT/230. 2020. ŁUKOMET [Internet]. [accessed 2021 Jan 20]. https://www.lukomet.pl/ deszczownia-szpulowa-irtec-50gbt230-p3325

158. Wiatkowski M., Wiatkowska B. 2019. Changes in the flow and quality of water in the dam reservoir of the Mała Panew catchment (South Poland) characterized by multidimensional data analysis. Arch Environ Prot. 45(1):26-41.

159. Wilk P., Grabarczyk A. 2018. The effect of selected inviolable flow characteristics on the results of environmental analysis using the example of river $a b-$ sorption capacity. Arch Environ Prot. 44(2):14-25.

160. Witze A. 2018. In the future, will people have enough water to live? Sci News [Internet]. [accessed 2001 Jan 20]:vol. 194 no. 4. https://www.sciencenews.org/article/ future-will-people-have-enough-water-live

161. Woznicki S.A., Nejadhashemi A.P., Parsinejad M. 2015. Climate change and irrigation demand: Uncertainty and adaptation. J Hydrol Reg Stud. 3:247-264.

162. Wu P., Jin J., Zhao X. 2010. Impact of climate change and irrigation technology advancement on agricultural water use in China: A Letter. Clim Change. 100(3):797-805.

163. Zamir M.S.I., Yasin G., Javeed H.M.R., Ahmad A.U.H., Tanveer A., Yaseen M. 2013. Effect of Different Sowing Techniques and Mulches on the Growth and Yield Behavior of Spring Planted Maize (Zea Mays L.). Cercet Agron Mold. 46(1):77-82.

164. Zarski J., Dudek S., Kuśmierek-Tomaszewska R., Rolbiecki R., Rolbiecki S. 2013. Forecasting effects of plants irrigation based on selected meteorological and agricultural drought indices. Rocz Ochr Sr. 15(1):2185-2203.

165. Zarski J., Kuśmierek-Tomaszewska R., Dudek S. 2020. Impact of irrigation and fertigation on the yield and quality of sugar beet (Beta vulgaris L.) in a moderate climate. Agronomy. 10(2).

166. Zhang L., Merkley G.P., Pinthong K. 2013. Assessing whole-field sprinkler irrigation application uniformity. Irrig Sci. 31(2):87-105.

167. Zhuo L., Hoekstra A.Y. 2017. The effect of different agricultural management practices on irrigation efficiency, water use efficiency and green and blue water footprint. Front Agric Sci Eng. 4(2):185-194. 